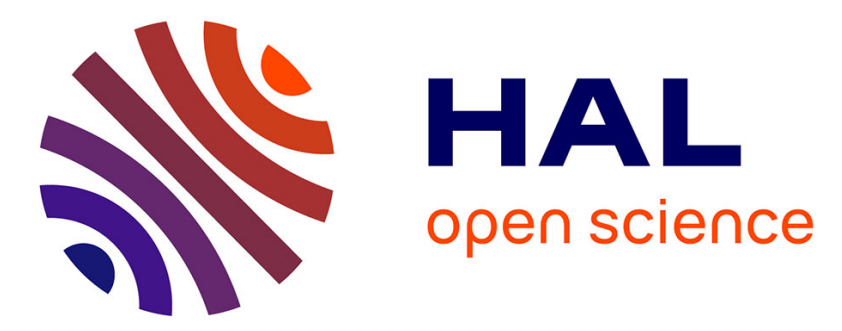

\title{
Population dynamics and environmental conditions affecting Trichodesmium spp. (filamentous cyanobacteria) blooms in the south-west lagoon of New Caledonia
}

\author{
Martine Rodier, Robert Le Borgne
}

\section{To cite this version:}

Martine Rodier, Robert Le Borgne. Population dynamics and environmental conditions affecting Trichodesmium spp. (filamentous cyanobacteria) blooms in the south-west lagoon of New Caledonia. Journal of Experimental Marine Biology and Ecology, 2008, 358 (1), pp.20-32. 10.1016/j.jembe.2008.01.016 . ird-00288736

\section{HAL Id: ird-00288736 \\ https://hal.ird.fr/ird-00288736}

Submitted on 18 Jun 2008

HAL is a multi-disciplinary open access archive for the deposit and dissemination of scientific research documents, whether they are published or not. The documents may come from teaching and research institutions in France or abroad, or from public or private research centers.
L'archive ouverte pluridisciplinaire HAL, est destinée au dépôt et à la diffusion de documents scientifiques de niveau recherche, publiés ou non, émanant des établissements d'enseignement et de recherche français ou étrangers, des laboratoires publics ou privés. 
Population dynamics and environmental conditions affecting Trichodesmium spp. (filamentous cyanobacteria) blooms in the south-west lagoon of New Caledonia Martine Rodier* and Robert Le Borgne ${ }^{1}$

* IRD, UR 167, Centre Océanologique de Marseille, Faculté des Sciences de Luminy, Case 901, 13288 Marseille Cédex 9, France

${ }^{1}$ Centre IRD, UR 103, B.P. A5, 98800 Nouméa Cédex, New Caledonia

*Corresponding author: rodier@ com.univ-mrs.fr

Suggested running head: Trichodesmium population dynamics

Keywords: Blooms, Population dynamics, Trichodesmium, Tropical lagoon 
1 Abstract. The present description of Trichodesmium spp. population dynamics and associated

2 environmental variables is the first one using a very short sampling interval (2-3 days). Such a

3 strategy allows a fine description of changes involving the population density and characteristics. It

4 also lends itself to interpreting those changes from past environmental conditions. During the two

5 surveys, 2 and 5 month-long, T. erythraeum dominated the Trichodesmium population, with

6 temporary occurrence of T. thiebautii and five blooms could be described. These events appeared at

7 temperatures $>24^{\circ} \mathrm{C}$ and followed, in all cases, nitrate, soluble reactive phosphorus and chlorophyll

$8 \quad a$ enrichments, with a 3-7 day time lag. Low wind speed $\left(<4 \mathrm{~m} \mathrm{~s}^{-1}\right)$ was not a prerequisite for

9 Trichodesmium bloom developments as long as temperatures exceeded $26^{\circ} \mathrm{C}$. As abundance

10 increased during the bloom, so did the number of filaments (trichomes) in colonies and their

11 buoyancy, leading to a clear positive biomass gradient from the bottom to the surface. A simple

12 model, using variable growth rates, showed trichome ascent would be responsible for $87-99 \%$ of

13 concentrations at $0.5 \mathrm{~m}$, with Trichodesmium net growth rates ranging from 0.11 to $0.38 \mathrm{~d}^{-1}$. Finally,

14 rapid trichome density declines could be ascribed to nutrient depletion and massive surface death

15 following ascent.

\section{Introduction}

High surface concentrations of the chain-forming diazotrophic cyanobacteria Trichodesmium spp.

21 have drawn attention, not only for their spectacular characteristics, but also for their potential toxicity (Landsberg, 2002, ) and contribution to the carbon and nitrogen cycles in oligotrophic regions via diazotrophy, i.e. di-nitrogen $\left(\mathrm{N}_{2}\right)$ fixation (Karl et al., 2002). Such natural phenomena, called "blooms" in most references, have often been observed in the south-west Pacific, both in the open ocean (Dupouy et al., 2000) and coastal areas (Jones et al., 1982), as well as in other parts of the tropical belt (Capone et al., 1997). While many causative mechanisms for bloom development 
have been proposed in the past (Sellner, 1997), we still lack reliable descriptions of past environmental conditions that triggered their increase. The word "bloom" itself remains imprecise and is generally understood as corresponding to rapid and intense growth, as it does for other phytoplankters, although it is now admitted that aggregation may be responsible for many observed surface Trichodesmium concentrations. One of the reasons for such uncertainties is that many reports are based on instant observations, no account being provided on past characteristics, biomass and vertical distribution of the Trichodesmium population, as stressed by Carpenter et al. (2004). Therefore, the understanding of bloom dynamics and causes would benefit from high frequency observations of both cyanobacteria and environmental variables over the water column.

Such a strategy, involving very frequent sampling on a long period of time can virtually be made in coastal areas, only. Present knowledge, however, rely on rather low frequency observations with sampling being made every 7 - 15 days (Lugomela et al., 2002), 1 month (Post et al., 2002) or 10 15 days (Muslim and Jones, 2003). While correlations between simultaneous data on Trichodesmium densities and environmental variables could be evidenced in these studies (Post et al., 2002; Muslim and Jones, 2003), effect of potential bloom triggers and environmental conditions that are required for bloom developments were not clearly proved because no information was collected in the few days preceding the start of the blooming event. For the same reason, causes of high surface aggregations remained hypothetical for lack of high temporal resolution surveys of Trichodesmium density along the water column, so that discriminating between effects of growth, vertical migrations and physical aggregation was impossible. Such considerations led to organizing "high" frequency sampling at the entrance of the Bay of Ste Marie (Noumea, New Caledonia) with two surveys made during the austral spring and summer, as both seasons are reported to be favourable for bloom development. Surveys lasted for 2.5 (Survey I: 9 October - 19 December 2003) and 5 months (Survey II: 15 November 2004 - 12 April 2005) with field measurements made at the same station, three times per week. 
Here, we describe the Trichodesmium population, the changes in filament (trichome) density, degree of aggregation in colonies and vertical distribution during bloom development. From such a description and observed biovolume increase rates, we will show that high surface concentrations are due to growth and trichome ascent. Further, potential bloom triggers and favourable environmental conditions, will be identified from monitored environmental variables that prevailed between 2 and 7 days before. These variables were selected, taking into account results of the Muslim and Jones (2003) study in a similar shallow coastal site of the Great Barrier Reef (GBR, Australia): meteorology (wind strength and rainfall), hydrology (temperature and salinity), dissolved inorganic nutrients, turbidity, a proxy of suspended sediments, and chlorophyll, in addition to phytoplankton and zooplankton composition. Finally, one of the usual criticism of conclusions based on a solitary station deals with the effect of spatial heterogeneity on time-series data. This point will be considered taking into account observations made simultaneously at the entrance and $2.0 \mathrm{~km}$ off the bay.

\section{Materials and methods}

\subsection{Sampling sites and general conditions (Fig. 1)}

The study site, Sta. SM (22¹8.86' S - 166²7.95' E, Fig. 1), was visited every Monday, Wednesday and Friday, between 07:00 and 09:00. While the station is away from inhabited areas and from urban inputs, it is protected from the prevailing SE trade winds and swell. A second station, Sta. $\mathrm{O}\left(22^{\circ} 19.80^{\prime} \mathrm{S}-166^{\circ} 28.48^{\prime} \mathrm{E}\right)$ was visited in 2004-2005, weather permitting for comparison. Water column depth is $12 \mathrm{~m}$ and $28 \mathrm{~m}$ for Stas SM and O, respectively.

\subsection{Meteorology, hydrology, and water sampling}

Meteorological data were recorded at Faubourg Blanchot Meteo-France Station, $4.2 \mathrm{~km}$ away from the entrance of the Bay of Ste Marie. 
CTD profiles (1 m to bottom) were obtained with a SeaBird ${ }^{\circledR}$ SBE 19 probe, fitted with pressure, temperature, salinity, turbidity, fluorescence and Photosynthetic Available Radiation (PAR) sensors. Water samples were collected with 5 L-Niskin bottles at 0.5, 4, 7, and $10 \mathrm{~m}$ in 2003 and 0.5, 3, 6, and $10 \mathrm{~m}$ in 2004-2005. Niskin bottles were siphoned in the laboratory on land for nutrient and pigment analyses and Trichodesmium abundance, within one hour of sampling.

\subsection{Nutrients and pigments}

Nutrients were analyzed on $\mathrm{HgCl}_{2}$-preserved samples from 0.5 and 6-7 m. Nitrate $\left(\mathrm{NO}_{3}\right)$ concentrations were determined by colorimetry using a Technicon ${ }^{\circledR}$ auto-analyzer and standard techniques (Strickland and Parsons, 1972), except for $\mathrm{NO}_{3}<0.1 \mu \mathrm{M}$, when the "high sensitivity" procedure of Raimbault et al. (1990) was used. Soluble reactive phosphorus (SRP) concentrations were measured with a Cecil ${ }^{\circledR} \mathrm{CE} 1011$ (10cm length-cell) spectrophotometer, using the molybdenum blue reaction (Murphy and Riley, 1962).

Chlorophyll $a(\mathrm{Chl} a)$ was measured on the $<20$ and $>20 \mu \mathrm{m}$ size fractions at all sampled depths, except for the $>20 \mu \mathrm{m}$ fraction in 2004-2005, when analyses were only made at 3 and $10 \mathrm{~m}$. For the $<20 \mu \mathrm{m} \mathrm{Chl} a, 200 \mathrm{ml}$ were prefiltered through a $20 \mu \mathrm{m}$ nylon screen and collected on Whatman ${ }^{\circledR}$ GF/F filters. For the $>20 \mu \mathrm{m}$ fraction, the whole Niskin bottle content was filtered through a $20 \mu \mathrm{m}$ screen and gently rinsed off with filtered seawater onto GF/F filters. All filters were stored in liquid nitrogen until analysis within less than 2 weeks. Chl $a$ was extracted in methanol and measured by fluorometry as described by Le Bouteiller et al. (1992).

\subsection{Trichodesmium abundance and biometry}

Trichodesmium were collected on $20 \mu$ m nylon screen from the total content of Niskin bottles (mean volume: $5.74 \mathrm{~L}$ ) and transferred to a "sedimentation cell" with 5\% formaldehyde. When trichomes did not sink, a few drops of pure acetic acid were added to the cell, in order to lower solution $\mathrm{p}_{\mathrm{H}}$ and break gas vesicles (Carpenter and Carmichael, 1995). Microscopic examinations and 
104 enumeration were made $24 \mathrm{~h}$ later using a Leitz ${ }^{\circledR}$ Fluovert inverted microscope. Enumeration

105 considered free trichomes and fusiform (tuft) and spherical (puff) aggregates, usually called

106 "colonies" in the literature. The number of trichomes per colony was recorded and the volume of

107 each trichome was calculated from its measured length and diameter, assuming a cylindrical shape

108 for the organism. In this paper, Trichodesmium abundance has been expressed in terms of total

109 number of trichomes (i.e. free and in colonies) per litre (trich. $\mathrm{L}^{-1}$ ), or as trichome biovolume per

110 litre $\left(\mu \mathrm{m}^{3} \mathrm{~L}^{-1}\right)$. Integrated values have been computed by the trapezoidal method. While trichome

111 density and biovolume are closely related (Fig. 2), due to the fact that biovolume data includes

112 trichome numbers, biovolume is often preferred as it gives a better estimate of the biomass.

113 Two species of Trichodesmium were identified according to Carpenter and Carmichael (1995)

114 and Janson et al. (1995). Individual cells of T. thiebautii Gomont are more long than wide and the

115 trichome has a convex apex whereas T. erythraeum Ehrenberg cells are more wide than long and the

116 trichomes have a flat apex. T. erythraeum colonies are usually darker than T. thiebautii colonies

117 (Carpenter et al., 1993). Such morphological differences between the two species have also been

118 confirmed by genetic finger prints of Trichodesmium spp. sampled in different areas of New

119 Caledonia, considering the hetR and rrs encoding for 16S rDNA genes, the internal transcribed

120 spacer (ITS) of the 16S-23S rDNA region and a highly iterated palindrome, HIP1 (Trottet, 2003).

\subsection{Trichodesmium $C, N$ and chlorophyll a contents}

Plankton nets (35- $\mu \mathrm{m}$ mesh), towed at $1 \mathrm{~m}$ below the surface, were the source of $18-75$ colonies hand-picked, using a plastic inoculation loop, and transferred onto $25 \mathrm{~mm}$ Whatman GF/F filters for Chl $a$ measurements, or on pre-combusted filters for carbon (C) and nitrogen (N) analyses.

Filters for Chl $a$ measurements were stored in liquid nitrogen and analyzed as described above. 
129 assimilation and nitrogen fixation experiments using ${ }^{13} \mathrm{C}$ and ${ }^{15} \mathrm{~N}$ techniques (data not shown here, 130 but reported in Le Borgne et al., 2006).

131 Carbon, $\mathrm{N}$ and $\mathrm{Chl} a$ contents are expressed per colony $\left(\operatorname{col}^{-1}\right)$ and per trichome $\left(\right.$ trich. $\left.{ }^{-1}\right)$. Since 132 analyses were made on colonies originating from plankton nets, the mean number of trichomes per 133 colony was obtained from microscopic observations of aliquots originating from the same catches 134 and processed as described before.

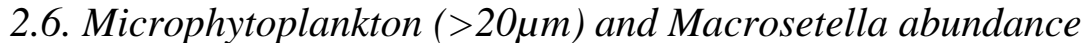

137 Counts of the major phytoplankton taxa were conducted on samples from 2004-2005 survey.

138 Selected taxa were diatoms, dinoflagellates and Trichodesmium spp. The two specific

139 Trichodesmium spp. grazers, copepods Macro- and Microsetella spp. (Roman, 1978; O'Neil and

140 Roman, 1994) were all enumerated on all samples. They were grouped into the "Macrosetella"

141 taxon, since Macrosetella gracilis is the most abundant species in both our samples and lagoons of 142 the west coast of New Caledonia (Binet, 1984).

\subsection{Trichodesmium biovolume net increase and carbon-specific growth rates}

Using observed Trichodesmium biovolume increases, $\Delta \mathrm{Vi}$, exponential net increase rates, ki (in $\left.\mathrm{d}^{-1}\right)$, can be calculated at depth, zi:

$$
\Delta \mathrm{Vi}=\mathrm{V}_{\mathrm{f}, \mathrm{i}}-\mathrm{V}_{\mathrm{o}, \mathrm{i}} \text { with } \mathrm{V}_{\mathrm{f}, \mathrm{i}}=\mathrm{V}_{\mathrm{o}, \mathrm{i}} \mathrm{e}^{\mathrm{ki} \mathrm{t}} \Rightarrow \mathrm{ki}=\ln \left(\mathrm{V}_{\mathrm{f}, \mathrm{i}} / \mathrm{V}_{\mathrm{o}, \mathrm{i}}\right) /\left(\mathrm{t}_{\mathrm{f}}-\mathrm{t}_{\mathrm{o}}\right)
$$

where $\mathrm{V}_{\mathrm{f}, \mathrm{i}}$ is the maximum biovolume of a peak period at time $\mathrm{t}_{\mathrm{f}}$ and $\mathrm{V}_{\mathrm{o}, \mathrm{i}}$, at the initial time $\mathrm{t}_{\mathrm{o}}$.

151 Biovolume-based doubling time, $\mathrm{d}_{\mathrm{A}, \mathrm{i}}$ (in $\mathrm{d}$ ), is equal to:

$$
\mathrm{d}_{\mathrm{A}, \mathrm{i}}=\ln (2) / \mathrm{ki}=\ln (2)\left(\mathrm{t}_{\mathrm{f}}-\mathrm{t}_{\mathrm{o}}\right) /\left(\ln \left(\mathrm{V}_{\mathrm{f}, \mathrm{i}} / \mathrm{V}_{\mathrm{o}, \mathrm{i}}\right)\right)
$$


155 The carbon-specific growth rate for $0.5 \mathrm{~m}$ depth, $\mathrm{g}_{\mathrm{C}, 0.5}$, was obtained from ${ }^{13} \mathrm{C}$ primary

156 productivity and elemental composition measurements, made on colonies in 2004-2005 (data

157 presented in Le Borgne et al., 2006). Calculations of $\mathrm{g}_{\mathrm{C}, 0.5}$ used the following equation:

$$
\mathrm{gc}_{, 0.5}=\ln \left(\left(\mathrm{Co}+\rho_{\mathrm{C}}\right) / \mathrm{Co}\right)
$$

161 where Co is the initial carbon concentration, $\rho_{\mathrm{C}}$ is the daily rate of carbon fixation, and time is understood as one day.

\subsection{Data processing}

Non-parametric and Gaussian statistics were used, following Snedecor and Cochran (1967).

Bravais-Pearson and Spearman's rank correlation coefficients are $r$ and $r_{S}$, respectively, with level of significance shown by $*$ and $* *$ for $\mathrm{p}<0.05$ and $\mathrm{p}<0.01$ significance, respectively; $n$ is the number of data per series, $s$, the standard deviation and $p$, the probability of rejection in the Wilcoxon and sign tests.

\section{Results}

\subsection{Trichodesmium population dynamics: abundance, vertical distribution and net increase rates}

Trichodesmium spp. were always present, at least at one of the sampled depths and made almost the totality of the pelagic filamentous cyanobacteria, Katagnymene spp. being quasi-absent. $T$. erythraeum was the dominant species in 2003 (99.0\% of the 5,513 counts) and 2004-2005 (83\% of the 10,650 counts) with $T$. thiebautii making the remainder.

Amidst a background of low trichome concentration, several periods of abrupt increase and decline were observed during the two surveys (Fig. 3 and 4). When the abundance exceeded 5 
181 thriving. Given the sharp variations, the term "bloom" will be used hereafter even though it is not 182 quite appropriate, in the sense that the Trichodesmium never dominated the microphytoplankton, 183 contributing a maximum of $27.7 \%$ of microphytoplankton counts.

184 Five blooms were observed with various features summarized in Table 1. Each bloom was 185 characterized by one peak abundance, except in 2003, when the 3 consecutive maxima were 186 interpreted as belonging to the same bloom (see Discussion). Peak amplitudes were variable from 187 one event to another and that of February 2005, although low, was considered as a bloom because 188 trichome densities were above $5 \mathrm{~L}^{-1}$ for 3 weeks. T. erythraeum was responsible for most of the 189 blooms, except in December 2004 and February 2005 when contribution of T. thiebautii was 190 significant. A striking point was the vertical distribution during the blooms, with a clear positive 191 gradient of trichome densities from deep to shallow depths (Fig. 3 and 4).

192 During the peak periods, the exponential net increase rate, ki, (equation 1), ranged from 0.19 to $1931.51 \mathrm{~d}^{-1}$ at 6-7 and $10 \mathrm{~m}$ and from 0.52 to $3.29 \mathrm{~d}^{-1}$ at 3-4 and $0.5 \mathrm{~m}$ (Table 2). These ki values were 194 higher than carbon-specific growth rates, $\mathrm{g}_{\mathrm{C}, 0.5}$, calculated from ${ }^{13} \mathrm{C}$ uptake rates at $0.5 \mathrm{~m}$ : $0.12-0.17$ $195 \mathrm{~d}^{-1}$ (Le Borgne et al., 2006). Exponential net increase rate calculations from biovolume variations 196 were not possible outside the peak periods, while carbon-specific growth rates, $\mathrm{g}_{\mathrm{C}, 0.5}$, provided by 197 the ${ }^{13} \mathrm{C}$ uptake method were low, $0.022 \mathrm{~d}^{-1}$ on average (range: $0.017-0.050 \mathrm{~d}^{-1}$ ).

198 Finally, density variations were synchronized and of the same magnitude at stations SM and O 199 (Fig. 4) except from February 2005 on, when higher Trichodesmium densities were often found at 200 the latter site. Growth rates, estimated from the ${ }^{13} \mathrm{C}$ experiments at both stations were similar (Le 201 Borgne et al., 2006).

3.2. Trichodesmium population features: trichome size, degree of aggregation and chemical constituents

205 For both surveys, biovolume per trichome displayed quite a large range (Table 3), their length 206 variability was greater than the width one and T. thiebautii trichomes were significantly longer than 
those of T. erythraeum $(p<0.001)$. There was no significant size difference between trichomes from 0.5 and $6 \mathrm{~m}$, as well as from Sta. SM and O (not shown) and between 2003 and 2004-2005 for both species.

During the two surveys, Trichodesmium population consisted mostly of free trichomes $(65 \pm 22$

and $63 \pm 15 \%$ in 2003 and 2004-2005, respectively) and colonies in tuft morphology prevailed

212 (98\% of the total number of colonies). Tufts were typically small, made of 2 to 34 trich. col $^{-1}$ while

213 puffs of $T$. thiebautii were made up of 7 to 123 trich. $\mathrm{col}^{-1}$. As the number of free trichomes

214 increased during the peak periods, so did the number of trichomes in colonies, leading to a

215 significant correlation between the two forms ( $p<0.01$; Fig. 5). Regression curves between densities 216 of trichomes in colonies and free trichomes were calculated for each of the two periods, using a 217 semi-log scale in order to take the anormal distribution of the free trichomes into account (Fig. 5).

218 Trichodesmium carbon, nitrogen and Chla content data, presented in Table 4, were quite variable, 219 likely due to different physiological or trophic states of filamentous cyanobacteria. Based on 220 trichome densities and $\mathrm{Chl} a$ content, Trichodesmium $\mathrm{Chl} a$ was estimated as accounting for no more 221 than $21 \%$ of total $\mathrm{Chl} a$. Atomic $\mathrm{C} / \mathrm{N}$ ratio averaged 6.2 (range: $4.6-7.4$ ), a value close to the slope 222 (6.75) of the $\mathrm{C}$ versus $\mathrm{N}$ regression line $\left(r^{2}=0.96, n=10\right)$ and to the Redfield ratio.

To sum up, present surveys evidenced a shallower vertical distribution, higher growth rates and more trichome aggregation in colonies during Trichodesmium blooms. These are the result of environmental changes that are now considered.

\subsection{General environmental conditions and causes of bloom developments (Fig. 6 and 7)}

Both surveys started in austral spring, a season characterized by settled SE trade winds $\left(>6 \mathrm{~m} \cdot \mathrm{s}^{-1}\right)$ and low rainfall. Sea temperature increased gradually until the beginning of February (Survey II), reaching $29^{\circ} \mathrm{C}$. Amidst this increasing trend, windy periods induced lower sea temperature and higher salinity in spring. In summer and autumn, however, effect of wind on salinity was the opposite, wind being associated to heavy rainfalls brought by tropical depressions, Kerry being one 
233 of them in January 2005. Their major effect was high rainfall on the mainland and resulting lower 234 lagoon salinity $(<35.00)$.

235 Nutrient concentration increases followed local rainfall, as recorded at Noumea Met station in 236 most instances. When they did not, they could be due, either to regional precipitation, not necessarily 237 recorded by coastal stations, or to wind events leading to resuspension of shallow sediments and 238 associated benthic nutrients (Muslim and Jones, 2003). The latter interpretation might indeed explain 239 the nitrate peaks of November 2003 (Fig. 6) and March 2005 (Fig. 7) and the peak of SRP of 240 January 2005, that took place during windy periods with no rainfall.

241 These increases in nutrient concentrations were not necessarily followed by total Chl $a$ peaks for reasons probably linked to vertical mixing or trace metal inhibitions, as discussed later for Trichodesmium. Microphytoplankton contributed $15.9 \%(s=8.0 ; n=119)$ to total Chl $a(>20 \mu \mathrm{m}+$ $<20 \mu \mathrm{m})$ in 2003 and $8.0 \%(s=7.2 ; n=130)$ in 2004-2005. Their main peak period occurred in February 2005, following January nutrient inputs (Fig. 7). Diatoms dominated the microphytoplankton, contributing $82 \%$ of the counts and dinoflagellates made most of the remainder $(11 \%)$

Trichodesmium sp. started thriving at a water temperature, ranging from 24.2 to $28.6^{\circ} \mathrm{C}$ (Fig. 6 and 7). The vertical temperature gradient was variable from one bloom event to the other $(0.05$ to $0.84^{\circ} \mathrm{C}$ ) and, therefore, did not seem to affect Trichodesmium development. The same conclusion may be drawn for the vertical salinity gradient which ranged between 0.00 and 1.00 .

A calm period (mean wind speed $<4 \mathrm{~m} \mathrm{~s}^{-1}$ ) preceded development of Trichodesmium blooms, except in January 2005 (Fig. 7) when the bloom started and continued during a windy period (mean wind speed before the bloom commenced: $7.3 \mathrm{~m} \mathrm{~s}^{-1}$ ). In this case, however, temperature was $>26^{\circ} \mathrm{C}$. In the other instances, windy periods did prevent Trichodesmium growth, as observed in NovemberDecember 2003, for example. Higher turbidity was not systematically associated with wind speed and rather low turbidity was the rule most of the time. We conclude turbidity, as measured by the CTD sensor, is not a good descriptor of blooming conditions. 
Trichodesmium always (5/5 cases) throve after nutrient $\left(\mathrm{NO}_{3}, \mathrm{SRP}\right)$ and $\mathrm{Chl} a$ concentration

260 increases, that occurred within 3-7 days before the peak abundance (Fig. 6 and 7). Since it happened 261 in all 5 cases, its occurrence was significant (sign test at $p<0.10$ ). In addition, amplitude of the peak 262 abundance at $0.5 \mathrm{~m}$ was significantly correlated $\left(r_{S}=0.879^{*}\right)$ with $\mathrm{NO}_{3}$ concentration at the start of 263 the bloom (Fig. 8), but not with SRP.

264 In order to test the nutrient and Chl $a$ trigger hypothesis, we have considered whether all of their 265 increases were followed by blooms. During the two surveys, there were only two exceptions (5-7 266 November 2003 and 10-14 January 2005) when nutrient enrichments did not lead to any 267 development. In those two cases, the nutrient-Chl $a$ increases were followed by windy periods (Fig. 2686 and 7) which could, therefore, prevent bloom development. However, as seen previously, the wind 269 factor alone may not explain the second exception (January 2005) since temperature was $>26^{\circ} \mathrm{C}$. A 270 lower than usual salinity may be the direct or indirect reason for the lack of Trichodesmium bloom as 271 it was also for the lack of microphytoplankton biomass increase at the same period (Fig. 7). In summary, according to the present observations, development of Trichodesmium blooms would follow nutrient and $\mathrm{Chl} a$ concentration increases with a 3-7 day lag, provided temperature is $>26^{\circ} \mathrm{C}$ and no heavy and sustained rainfall occurs. The same conditions apply to $>24^{\circ} \mathrm{C}$ temperatures, as long as wind speed is low $\left(<4 \mathrm{~m} \mathrm{~s}^{-1}\right)$.

\section{Discussion}

\subsection{Sampling strategy: are conclusions drawn from one station valid?}

Study of Trichodesmium population dynamics employed high frequency sampling at Sta. SM, 281 assuming the same watermass and planktonic population were sampled for a long enough period. 282 This implies a rather long residence time, which is supported by the study of Jouon et al. (2006). 283 Thus, the "e-flushing time", a proxy of the water residence time, is 15-25 days at the entrance of the 284 bay, for a $\sim 8 \mathrm{~m} \mathrm{~s}^{-1}$ (15.5 knots) SE wind velocity, and longer, of course, for lower wind speeds. 
285 Besides, no significant tide effect was evidenced, especially in terms of salinity at $1 \mathrm{~m}$ depth, because 286 water exchanges proceed from both the south and the east of Sta. SM (Fernandez et al., 2006). Note 287 also that Trichodesmium density and environmental parameter variations at Sta. SM displayed no 288 erratic trends, at least at a period of a week. It appears, therefore, that this station lent itself to a 289 satisfactory temporal description.

290 Moreover, present observations were representative of the surrounding lagoon waters, as seen for 291 the following parameters: (1) Trichodesmium spp. densities and microplankton abundance at $0.5 \mathrm{~m}$ 292 were in a fair agreement at the two stations even though Trichodesmium densities became higher out 293 of the bay from February 2005 on. (2) Proportions of the two Trichodesmium species or of other 294 microphytoplankton taxa were not significantly different at Sta. SM and O and (3) Trichodesmium 295 spp. growth rates, as provided by the ${ }^{13} \mathrm{C}$ method, were similar at the two stations. All these 296 arguments support the view of a reasonable spatial homogeneity in the sampled area, which is the 297 prerequisite to temporal variation descriptions.

\subsection{Trichodesmium population characteristics}

Density as compared to other studies. Trichomes have been observed systematically during the two surveys and appeared to be a component of the usual phytoplankton population, as happens in the GBR where they would occur in $83 \%$ of the samples (Jones, 1992). However, they never made the bulk of the phytoplankton at Sta. SM, with their Chl $a$ accounting for no more than $21 \%$ of the total. Similar contributions were reported by Letelier and Karl (1996) and Dupouy et al. (2000) for the open ocean of the tropical Pacific although higher values (11-62\%) were found in the Atlantic by Carpenter et al. (2004). reported in this study, are rather modest compared to those found in the literature (Table 5) and this may be explained by differences in both methods and environmental conditions. Use of a $20 \mu \mathrm{m}$ mesh, trichome transfer from the silk into the sedimentation cell, insufficient trichome sinking 
311 (Lugomela et al., 2002) or use of a 5.74 L sampling bottle instead of a net (Chang, 2000) may be

312 reasons linked to the methodology. In addition, present results refer to samples at $0.5 \mathrm{~m}$ while some

313 of the reported densities in the literature refer to the very near-surface (i.e. $0 \mathrm{~m}$ ), where much higher

314 concentrations could be associated with discoloured waters and accumulations along fronts or

315 Langmuir cells. It remains some of the high densities found in literature refer to subsurface maxima

316 (e.g. 12-24 m of Carpenter et al., 2004) and not to the very top surface, leading us to look for

317 environmental-related reasons. Thus, an element may limit growth of the filamentous cyanobacteria

318 and it is probably not dissolved iron, given its very significant concentrations in the SW lagoon,

319 ranging between 2 and $5 \mathrm{nM}$ (unpublished data). These values are much above $1 \mathrm{nM}$, the

concentration given by Sanudo-Wilhelmy et al. (2003) for areas of non Fe-limited diazotrophy in the

Atlantic ocean. Phosphorus, however, could be the limiting element of primary production,

considering that its two possible sources are phosphorus depleted: runoffs from lateritic soils of this part of New Caledonia (Tenorio et al., 2005) and exchanges with the surrounding oligotrophic ocean

(Van Den Broeck et al., 2004). This limitation could explain both the modest trichome density maxima and the low Chl $a\left(<1 \mathrm{mg} \mathrm{m}^{-3}\right)$ concentrations (Fig. 6 and 7). Lastly, the observed positive and significant correlation found between trichome and diatom densities $\left(\mathrm{r}_{\mathrm{S}}=0.395^{* *} ; \mathrm{n}=41\right)$ would suggest no negative effect of the main component of the microphytoplankton on

328 Trichodesmium. In conclusion, modest trichome density maxima of the present study might result 329 from a combination of different factors, the main one being possibly phosphorus limitation. Specific composition. T. erythraeum was the dominant species with temporary occurrence of $T$.

331 thiebautii. The two species have distinct morphometric characteristics and they displayed much 332 higher length variations at Sta. SM (Table 3) than those reported by Post et al. (2002) in the Gulf of 333 Aqaba: 300 - $800 \mu \mathrm{m}$ for T. erythraeum and 1000 - $2000 \mu \mathrm{m}$ for T. thiebautii.

334 T. erythraeum dominance at Sta. SM, as in the GBR lagoon (Jones, 1992; Muslin and Jones, 335 2003) or the Tanzanian coast (Lugomela et al., 2002 ; Bryceson and Fay, 1981), the Mississipi 336 plume (Eleuterius et al., 1981) or the Bresilian coasts (Satô et al., 1963) might lead to the conclusion 
337 it would be found more often in coastal areas than T. thiebautii. This seems to be corroborated by 338 observations made in the open ocean off the east coast of New Caledonia, where T. erythraeum 339 makes only 20-25\% of the Trichodesmium filaments, while T. thiebautii and T. tenue would make $34040-45 \%$ and $30 \%$ of the total, respectively (Tenorio, 2006). Actually, each of the two species is able 341 to prevail in the open ocean. It is T. erythraeum in the Coral Sea and T. thiebautii in the Caribbean 342 Sea (O’Neil et al., 1996 ), T. thiebautii in the Kuroshio area (Saino and Hattori, 1980) and the 343 Atlantic (Carpenter et al., 2004), but T. erythaeum in the north Indian Ocean (Capone et al., 1998). 344 Therefore, it seems unlikely that dominance of the two species would rely on the "hemisphere" as 345 suggested by Capone and Carpenter (1999), but rather on physiological and/or environmental 346 conditions, such as those prevailing in rather closed coastal areas, that seem to be more appropriate 347 to T. erythraeum. Such a feature may be explained by a lower diazotrophic capacity of this species 348 (Carpenter et al., 1993), which would imply its preference for less oligotrophic areas than $T$. 349 thiebautii, on the one hand, and by less resistance of its vacuoles to pressure, which means less 350 adaptation to deep environments, on the other hand (Carpenter et al., 1993).

351 Contribution of trichomes in colonies to total. Most (98\%) of the colonies were of the tuft type 352 and made of $<20$ trichomes, on average. Similar numbers were found for T. erythraeum by 353 Bryceson and Fay (1981) and Capone et al. (1998) with respectively, 5.5-10 and 10-30 trich. col $^{-1}$. 354 But Carpenter et al. (2004), Letelier and Karl (1996) and Post et al. (2002) reported numbers > 100 355 for both T. erythraeum and T. thiebautii.

356 Also variable in the literature is the proportion of the number of aggregated trichomes to total 357 number of trichomes, or "bundleness" (Bryceson and Fay, 1981): ratios <20\% were observed in the 358 North Pacific (Saino and Hattori, 1980 ; Letelier and Karl, 1996) and in the Atlantic (Orcutt et al., 3592001 ; Tyrell et al., 2003) while bundleness ranged from 25 to $90 \%$ off the Tanzanian coast 360 (Bryceson and Fay, 1981) and in the tropical Atlantic (Carpenter et al., 2004). Such variability is 361 discussed by the latter authors and could originate from damages to the colonies during the sampling 362 and sorting processes, too small a sampled volume, and/or a "fundamental difference in the state of 
363 trichomes" between the different regions. Further, Orcutt et al. (2001), Fu and Bell (2003b) and Bell

364 et al. (2005) suggest there would be more of free trichomes during the optimum growth phase, and

365 more aggregation during the non optimum phases. Effect of wind speed and related water turbulence

366 on bundleness is invoked by Bryceson and Fay (1981) and would be negative, although the present

367 work does not support such a view, with bundleness not lower than usual during the windy January

3682005 peak. More simply, present observations (Fig. 5) suggest bundleness would follow encounter

369 probability law, i.e. the higher the trichome density, the higher the probability, thus agreeing with the

370 view of Carpenter et al. (2004) of density-related bundleness. But, whatever the factors involved in

371 colony formation, high bundleness seems to be typical of Trichodesmium blooms and responsible for

372 higher nitrogen fixation rates (Saino and Hattori 1980; Bryceson and Fay, 1981; Letelier and Karl, 373 1998; Capone, 2001).

\subsection{Trichodesmium bloom features: respective roles of growth and ascent}

A striking result in the present study and many other publications, is the intensity of

Trichodesmium density increases, which appear to be inversely related to depth (Table 2): the

shallower the level, the greater the increase. Moreover, doubling times d' ${ }_{\mathrm{A}}$, calculated on biovolume increases at 0.5, 3 - 4 and 6-7 $\mathrm{m}$ (Table 2), are much shorter than those reported in the literature for growth (Table 6), while d' ${ }_{\mathrm{A}, 10}$ at $10 \mathrm{~m}$ are in good agreement. From these observations, we conclude $\mathrm{d}_{\mathrm{A}, 10}$ mainly result from growth and $\mathrm{d}_{\mathrm{A}, \mathrm{i}}$ of shallower depths, result from growth plus another process. The latter is very likely the trichome ascent due to their positive buoyancy, a process which delivers them more or less rapidly to the surface as they grow and which would explain the observed vertical density gradient from the bottom to the surface (Fig. 3 and 4). Inversely, this gradient cannot

385 be ascribed to trichome sinking because microscopic observations showed healthy trichomes at all depths and no or few trichomes were retrieved in sediment traps of the 2003 survey (Le Borgne et al., 2004). 
Trichodesmium positive buoyancy is well known and T. erythraeum has been reported more buoyant than T. thiebautii (Carpenter et al., 1993; Lugomela et al., 2002), which would explain the modest increases of February 2005 at $0.5 \mathrm{~m}$ when $T$. thiebautii contribution was significant. Such positive buoyancy, linked to the presence of gas vesicles (Capone et al., 1997), is different from that governing daily up and down vertical motion, with diel variations of the carbohydrate to protein ratio (Villareal and Carpenter, 2003).

In order to test whether trichome biovolume increases ( $\Delta \mathrm{Vi}$ ) observed during the bloom periods, resulted from both their net growth (Gi) and ascent (Ai) from deeper levels and in order to estimate the respective contributions of the two processes, we used a simple model. Provided spatial heterogeneity is negligible, as compared to temporal variability (see 4.1.), observed $\Delta \mathrm{Vi}$ at depth zi, between $t_{0}$ and $t_{f}$ (see eqn (1)) may be ascribed to the sum of Gi and Ai:

$$
\Delta \mathrm{Vi}=\mathrm{V}_{\mathrm{f}, \mathrm{i}}-\mathrm{V}_{\mathrm{o}, \mathrm{i}}=\mathrm{Gi}+\mathrm{Ai} \leftrightarrow \Delta \mathrm{Vi}-(\mathrm{Gi}+\mathrm{Ai})=0
$$

with $\mathrm{Gi}=\sum_{t=t o}^{t f} \mathrm{~V}_{\mathrm{o}, \mathrm{i}} \mathrm{e}^{\text {gi } \mathrm{t}} \Delta \mathrm{t}$, gi, being the exponential net growth rate, $\Delta \mathrm{t}$, the time interval.

Corresponding doubling time, $\mathrm{d}_{\mathrm{A}, \mathrm{i}}$, is equal to: $\mathrm{d}_{\mathrm{A}, \mathrm{i}}=\ln (2) / \mathrm{gi}$. Now, assuming trichome ascent, Ai, would proceed at the same pace as growth and gi be the same along the water column, Ai will be the integral of Gi with depth: $\mathrm{Ai}=\sum_{z=12}^{z i} \mathrm{Gi} \Delta \mathrm{z}=\sum_{t=t o}^{t f} \sum_{z=12}^{z i} \mathrm{~V}_{\mathrm{o}, \mathrm{i}} \mathrm{e}^{\text {gi }} \Delta \mathrm{t} \Delta \mathrm{z}$, where $\Delta \mathrm{z}$ is the difference between two sampled depths and $12 \mathrm{~m}$, the Sta. SM depth.

Calculations of $\mathrm{Ai}$ and $\mathrm{Gi}$ have been made for $\mathrm{zi}=0.5 \mathrm{~m}$, with the following $\Delta \mathrm{z}: 12-10 \mathrm{~m}, 10-7$ $\mathrm{m}, 7-4 \mathrm{~m}, 4-0.5 \mathrm{~m}$ in 2003 and 12-6 $\mathrm{m}$ and 6-0.5 $\mathrm{m}$ in 2004-2005. We solved equation (4), and considered the realism of computed doubling times, $\mathrm{d}_{\mathrm{A}, 0.5}$ (Table 7). Except for the December 2004 event, $\mathrm{d}_{\mathrm{A}, 0.5}$ values $(1.82-6.45 \mathrm{~d})$ are within the range of the doubling times in the literature (Table 6) and include the December 2003 biovolume doubling time at $10 \mathrm{~m}, \mathrm{~d}_{\mathrm{A}, 10}=2.9 \mathrm{~d}$ (Table 2). The December 2004 low $\mathrm{d}_{\mathrm{A}, 0.5}$ value (0.53 d) may be ascribed to an underestimated initial biovolume, 
413 Vo, 0.5 , which is used in equation 4. Estimates of $A_{0.5}$ and $G_{0.5}$ show that most (87 to $99 \%$ ) of

414 biovolume increase observed at $0.5 \mathrm{~m}\left(\Delta \mathrm{V}_{0.5}\right)$, would be due to $\mathrm{A}_{0.5}$. Ascent contribution variability

415 might be linked to the mixing intensity of the water column, as illustrated by the windy January 2005

416 bloom, which had the lowest ascent contribution (Table 7).

417 In this type of calculation applied to peak periods, the growth rates (gi) varied from one peak 418 abundance to another $\left(\mathrm{g}_{0.5}=0.11-0.38 \mathrm{~d}^{-1}\right)$. They varied also between non bloom and bloom 419 periods, as illustrated by the carbon-specific growth rates, provided by ${ }^{13} \mathrm{C}$ uptake measurements. 420 Indeed, a ratio of 5.1 - 7.4 (see Results) between bloom and "normal" periods may be computed, 421 leading us to the next question: what is the origin of gi variations leading to bloom developments?

\subsection{Causes of bloom developments: favorable conditions and triggers}

These may be shared into necessary conditions which allow blooms to occur, and triggers that effect gi. The latter have been identified as nutrient increases during the 3-7 preceding days for all the blooms, which supports observations made by Carpenter and Price (1977), Bell et al. (1999), Muslim and Jones (2003) regarding a phosphate effect and Lugomela et al. (2002) about nitraterelated blooms. Because diazotrophy is phosphorus-dependent (Sanudo-Wilhelmy et al., 2001; Fu and Bell, 2003a; Mills et al., 2004), the role played by SRP in bloom developments seems to be obvious. Less straightforward, however, may look the $\mathrm{NO}_{3}$ increase effect on diazotrophic cyanobacteria growth. In fact, di-nitrogen fixation is usually low or absent when other nitrogenous compounds are available since it is high energy demanding and repressed by $\mathrm{NH}_{4}$ (Mulholland and

433 Capone, 2000; Karl et al., 2002). At Sta SM, very low ${ }^{15} \mathrm{~N}_{2}$ fixation rates were indeed measured on 434 Trichodesmium colonies during the March-April 2005 bloom (Le Borgne et al., 2006), suggesting 435 most of their nitrogen needs were fulfilled by other compounds. Ammonium and very small 436 dissolved organic nitrogen (DON) molecules, which are released or produced by the microbial loop, 437 seem to be the best candidates, although such a statement cannot be proved for a lack of measurements. 
Then we get to the following scenario which fits observations at Sta SM. Observed Chl $a$

440 increases are very quick responses to $\mathrm{NO}_{3}$ inputs. Part of the $\mathrm{Chl} a$ increases may be due to diatoms, 441 which have a higher $\mathrm{NO}_{3}$ uptake capacity than most phytoplankters (Sarthou et al., 2005), and likely 442 respond immediately to nutrient inputs and lead to higher concentrations of ammonium and small 443 DON molecules through bacterial remineralization and microzooplankton grazing. These are taken 444 up eventually by filamentous cyanobacteria with a 3-7 d time-lag between $\mathrm{NO}_{3}$ increases and 445 Trichodesmium bloom initiation. The direct relation between Trichodesmium and diatom densities 446 reported before may therefore be interpreted in this way.

447 The nutrient-related scenario suffers a troubling exception: the most important nutrient increase 448 of the two surveys, in January 2005, was followed nor by Trichodesmium nor by 449 microphytoplankton development, while the whole area was invaded by waters of lower than usual 450 salinity. The salinity may not be incriminated per se, considering maximum Trichodesmium growth 451 occurs in the 30 - 37 psu range (Fu and Bell, 2003b; Bell et al., 2005). It may rather indicate 452 important terrigenous inputs of suspended sediments and heavy metals and their possible inhibition 453 of microphytoplankton (including Trichodesmium) growth. Inhibition could proceed through light 454 limitation due to a heavy load of suspended particles. No significant increase in turbidity (data not shown) was observed, however. Different could be the heavy metals inhibitory effect and Fernandez et al. (2006) have shown $\mathrm{Fe}, \mathrm{Ni}, \mathrm{Cr}, \mathrm{Co}, \mathrm{Mn}, \mathrm{Cu}$ and $\mathrm{Sr}$ are issued from laterite weathering, and carried along from several estuaries, south of Noumea (e.g., La coulee, Fig. 1). There may be also an impact of the amount and type of organic matter from terrigenous origin, on the microphytoplankton, although this topic has not been documented, yet.

Bloom triggers work, provided necessary conditions are met, i.e. appropriate iron concentration, 461 temperature and wind velocity. As seen above, iron is probably non limiting in the present study, but sunny and calm weather conditions may be necessary ones as invoked in the past by many authors

463 (Eleuterius et al., 1981; Jones et al., 1992; Sellner, 1997; Lugomela et al. (2002) ; Muslim and 464 Jones, 2003 ; Carpenter et al., 2004). However, calm weather is not sufficient a condition because 
465 466 467 468 469

there may be blooms during long periods of wind, as illustrated by the January 2005 event. Based on this example, when temperature was $\sim 26^{\circ} \mathrm{C}$, we conclude that blooms may occur during windy periods, only if sea temperature is above this threshold value, thus confirming the Carpenter and Capone (1992) analysis on bloom conditions. Inversely, below $26^{\circ} \mathrm{C}$, a low wind velocity appears to be necessary for bloom development. The minimum temperature for them to occur is $24^{\circ} \mathrm{C}$ in the present study, which is less than the $25^{\circ} \mathrm{C}$ threshold of Chen et al. (2003). Combination of wind and temperature effects can be interpreted as the result of two antagonist actions on growth rates, positively correlated to temperature and negatively to wind induced-mixing. It follows that, when temperature reaches a threshold value, its effect on growth will overcome the negative effect of mixing.

\subsection{Decline origin}

One of the striking points in the two surveys, was the brevity of the bloom decline phase, as for the growing one. Decline may be ascribed to mortality and to a recruitment diminution due to a growth rate slowdown as for any population, even though they might have common origins. In the present study, most blooms ended with very low nutrient concentrations ( $<0.030 \mu \mathrm{M} \mathrm{NO}_{3}$ at the end of the December 2003 and February 2005 events and <0.030 $\mu$ M SRP for those of February and April 2005), which suggests nutrient exhaustion represents one of the decline causes, as mentioned already by Lenes et al. (2005) and Moutin et al. (2005). This process could reduce growth rates, in a way opposite to the nutrient increase effect described above, or induce mortality through a "Programmed Cell Death" (PCD) pathway (Berman-Frank et al., 2004, 2007). Viral lysis (Ohki, 1999) and PCD, caused by other factors than nutrient depletion, as listed by Berman-Franck et al. (2004), are other possible processes. Inversely, intense grazing is likely excluded, considering the low Macrosetella densities that were observed and their lack of relationship with trichome concentrations. But the present observations on trichome ascent and surface accumulation during bloom periods with no obvious sinking or downward migration do not exclude massive destruction 
491 by solar radiation as infra-red or ultra-violet rays, independently of other processes. The solar effect 492 is likely linked to the sea surface agitation, with a more rapid destruction during calm sea and low 493 wind conditions. On the whole, apart from trichome viral lysis or PCD, abrupt decay could be the 494 result of ascent to the very top surface, solar destruction and lack of new trichome formation for 495 nutrient exhaustion.

4.6. Summary of Trichodesmium bloom dynamics as illustrated by the November - December 2003

498 event

499 A summary of present conclusions on the bloom triggering factors (nutrient concentration 500 increases), necessary conditions (combination of wind and temperature effects) and causes of bloom 501 decay can be illustrated by the Nov-Dec 2003 event. Although it was made of three peak 502 abundances, the following description shows it was only one event (Fig. 6).

503 An increase in nutrient concentrations was observed on $19-21$ November for $\mathrm{NO}_{3}$ and 17 504 November for SRP. At that time, water temperature was around $24^{\circ} \mathrm{C}$ and development could not 505 start before the wind velocity diminished. This occurred on the $23^{\text {rd }}$ and was likely responsible for 506 the observed trichome density and biovolume increase between 21 and 28 November. On 29 507 November, while temperature was now $25^{\circ} \mathrm{C}$, but still $<26^{\circ} \mathrm{C}$, the wind started blowing again, which 508 resulted in the first trichome density diminution between 28 November and 3 December. The wind 509 slowed down between 4 and 5 December, allowing another Trichodesmium increase with a peak on 510 the $5^{\text {th }}$. Calm weather conditions lasted until the $11^{\text {th }}$, allowing trichome ascent and mortality at $0 \mathrm{~m}$ 511 with the resulting biovolume decrease at all depths between 5 and 8 December and a small 512 development between 10 and 12 December, once temperature had reached $26^{\circ} \mathrm{C}$. The bloom ended 513 when $\mathrm{NO}_{3}$ became exhausted $(<0.005 \mu \mathrm{M}$ at $0.5 \mathrm{~m})$, i.e. from the $10^{\text {th }}$, on.

\section{Conclusion}


Photosynthetic filamentous cyanobacteria of the Trichodesmium genus, display the same

517 physiological processes as the other co-occuring phytoplankton and have the same requirements. In

518 particular, dissolved nutrients are primarily involved in their growth processes. But the present

519 surveys have shown major differences, with very steep density variations and changes in the

520 cyanobacterial vertical distribution during the blooms, both being the result of the trichome positive

521 buoyancy. This characteristic has two consequences: (1) most of the biomass accumulation will

522 happen at $0 \mathrm{~m}$ and not in the water column; (2) once they have reached the very top surface,

523 trichomes will remain there, and eventually be destroyed. In addition, because of their toxicity, the

524 grazing control of the Trichodesmium population appears to be restricted to a few species, like

525 harpacticoid copepods (Hawser et al., 1992) and these were not abundant in the studied area. These 526 two features of the Trichodesmium population dynamics, i.e. effects of positive buoyancy and low

527 grazing losses, make it quite different from what happens to the rest of the phytoplankton

528 community. Such a statement, however, is based on observations of a T. erythraeum dominated 529 population, which is known to be more buoyant and less diazotrophic than T. thiebautii. Therefore, 530 bloom causes and characteristics of T. thiebautii populations might be different to some extent and 531 would deserve a similar study, related to the toxicity issue, this species being considered as more 532 toxic than T. erythraeum (Sellner, 1997; Landsberg, 2002).

\section{Acknowledgements}

This work was supported by IRD through its Research Units 103 and 167 and by the New Caledonian field site of Programme National Environnement Côtier (PNEC). Authors thank MeteoFrance for providing Met data and are indebted to Florent Abrahami, Miguel Clarque, Philippe Gérard, Jennifer Goujon, Alain Lapetite, Isabelle Mazzeo, and Catherine Rouchon for technical assistance at sea and in the laboratory. They thank Nicole Garcia and Patrick Raimbault for carbon 
and nitrogen analyses and data processing and Emma Rochelle-Newall and an anonymous referee for improvement suggestions of the manuscript.

\section{References}

Bell, P.R.F., Elmetri, I., Uwins, P., 1999. Nitrogen fixation by Trichodesmium spp. in the Central and Northern Great Barrier Reef lagoon: relative importance of the fixed-nitrogen load. Mar. Ecol. Prog. Ser. 186, 119-126.

Bell, P.R.F., Uwins, P.J.R., Elmetri, I., Phillips J.A., Fu, F.X., Yago, A.J.E., 2005. Laboratory culture studies of Trichodesmium isolated from the Great Barrier Reef Lagoon, Australia. Hydrobiologia 532, 9-21.

Berman-Frank, I., Bidle, K. D., Haramaty, L., Falkowski, P., 2004. The demise of the marine cyanobacterium, Trichodesmium spp., via an autocatalyzed cell death pathway. Limnol. Oceanogr. 49, 997-1005.

Berman-Frank, I., Rosenberg, G., Levitan, O., Haramaty, L., Mari, X., 2007. Coupling between autocatalytic cell death and transparent exopolymeric particle production in the marine cyanobacterium Trichodesmium. Environt. Microbiol. doi. : 10.1111/j. 14622920.2007.01257.x.

Binet, D., 1984. Copépodes planctoniques du lagon de Nouvelle-Calédonie: facteurs écologiques et associations d'espèces. Mar. Biol. 82, 143-156.

Bryceson, I., Fay, P., 1981. Nitrogen fixation in Oscillatoria (Trichodesmium) erythraea in relation to bundle formation and trichome differenciation. Mar. Biol. 61, 159-166.

Capone, D. G., Carpenter, E. J., 1999. Nitrogen fixation by marine cyanobacterium : historical and global perspectives. Bull. Inst. Océanogr. Monaco 19, 235-256.

Capone, D. G., Zehr, J. P., Paerl, H. W., Bergman, B., Carpenter, E. J., 1997. Trichodesmium, a globally significant marine cyanobacterium. Science 273, 1221-1229. 
Capone, D. G., Subramaniam, A., Montoya., J. P., Voss, M., Humborg, C., Johansen, A. M., Siefert, R. L., Carpenter, E. J., 1998. An extensive bloom of $\mathrm{N}_{2}$-fixing cyanobacterium Trichodesmium erythraeum in the central Arabian Sea. Mar. Ecol. Prog. Ser. 172, 281-292.

Carpenter, E. J., Price, C. C., 1977. Nitrogen fixation, distribution, and production of Oscillatoria (Trichodesmium) spp. in the western Sargasso and Caribbean Seas. Limnol. Oceanogr. 22, 6072.

Carpenter, E.J., Romans, K., 1991. Major role of the cyanobacterium Trichodesmium in nutrient cycling in the North Atlantic ocean. Science 254, 1356-1358.

Carpenter, E. J., Capone, D. G., 1992. Nitrogen fixation in Trichodesmium blooms. In: Carpenter, E. J., Capone, D. G., Rueter, J. G. (Eds.), Marine Pelagic cyanobacteria: Trichodesmium and other Diazotrophs. Kluwer Academic Publishers, Dordrecht, pp. 211-217.

Carpenter, E. J., Carmichael, W. W., 1995. Taxonomy of Cyanobacteria,. In: Hallegraeff, G. M., Anderson, D. M., Cembella, A. D. (Eds), Manual on Harmful marine algae. UNESCO, Paris, pp. 373-380.

Carpenter, E. J., O’Neil, J. M., Dawson, R., Capone, D. G., Siddiqui, P. J. A., Roenneberg, T., Bergman, B., 1993. The tropical diazotrophic phytoplankter Trichodesmium : biological characteristics of two common species. Mar. Ecol. Prog. Ser. 95, 295-304.

Carpenter, E. J., Subramaniam, A., Capone, D. G., 2004. Biomass and primary productivity of the cyanobacterium Trichodesmium spp. in the tropical N Atlantic ocean. Deep-Sea Res. I 51, 173203.

Chang, J., 2000. Precision of different methods used for estimating the abundance of the nitrogenfixing marine cyanobacterium, Trichodesmium Ehrenberg. J. Exp. Mar. Biol. Ecol. 245, 215224.

Chen, Y-B. L., Chen, H-Y., Lin, Y-H., 2003. Distribution and downward flux of Trichodesmium in the South China Sea as influenced by the transport from the Kuroshio Current. Mar. Ecol. Prog. Ser. 259, 47-57. 
Dupouy, C., Neveux, J., Subramaniam, A., Mulholland, M. R., Montoya, J. P., Campbell, L., Carpenter, E. J., Capone, D. G., 2000. Satellite captures Trichodesmium blooms in the southwestern tropical Pacific. Eos 81, 15-16.

Eleuterius, L., Perry, H., Eleuterius, C., Warren, J., Caldwell, J., 1981. Causative analysis on a nearshore bloom of Oscillatoria erythraea (Trichodesmium) in the Northern Gulf of Mexico. Northeast Gulf Science 5, $1-11$.

Fernandez, J-M., Ouillon, S., Chevillon, C., Douillet, P., Fichez, R., Le Gendre, R., 2006. A combined modelling and geochemical study of the fate of terrigenous inputs from mixed natural and mining sources in a coral reff lagoon (New Caledonia). Mar. Pollut. Bull. 52, 320331.

Fu, F.-X., Bell, P. R. F., 2003a. Factors affecting $\mathrm{N}_{2}$ fixation by the cyanobacterium Trichodesmium sp. GBRTRLI101. FEMS Microbiol. Ecol. 45, 203-209.

Fu, F.-X., Bell, P. R. F., 2003b. Effect of salinity on growth, pigmentation, $\mathrm{N}_{2}$ fixation and alkaline phosphatase activity of cultured Trichodesmium spp. Mar. Ecol. Prog. Ser. 257, 69-76.

Hawser, S.P., O’Neil, J.M., Roman, M.R. Codd, G.A., 1992. Toxicity of blooms of the cyanobacterium Trichodesmium to zooplankton. J. Applied Phycol. 4, 79-86.

Janson, S., Siddiqui, P. J. A., Walsby, A.E., Romans, K.M., Carpenter, E. J., Bergman, B., 1995. Cytomorphological characterization of the planktonic diazotrophic cyanobacteria Trichodesmium spp. from the Indian Ocean and Caribbean and Sargasso Seas. J. Phycol. 31, 463-477.

Jones, G. B., 1992. Effect of Trichodesmium blooms on water quality in the Great Barrier Reef Lagoon,. In: Carpenter, E. J., Capone, D. G., Rueter, J. G. (Eds.), Marine Pelagic Cyanobacteria: Trichodesmium and other Diazotrophs. Kluwer Academic Publishers, Dordrecht, pp. 273-287. 
Jones, G.B., Burdon-Jones, C., Thomas, F.G., 1982. Influence of Trichodesmium red tides on trace metal cycling at a coastal station in the Great Barrier Reef Lagoon. Oceanol. Acta Special Publication, 319-326.

Jouon, A., Douillet, P., Ouillon, S., Fraunié, P., 2006. Calculations of hydrodynamic time parameters in a semi-opened coastal zone using a 3D hydrodynamic model. Cont. Shelf Res.26, 13951415.

Karl, D., Michaels,A., Bergman, B., Capone, D. G., Carpenter, E.J., Letelier, R., Lipschultz, F., Paerl, H., Sigman, D., Stal, L., 2002. Dinitrogen fixation in the world's oceans. Biogeochemistry 57/58, 47-98.

Landsberg, J.H., 2002. The effects of harmful algal blooms on aquatic organisms. Rev. Fish. Sci. 10, 113-390.

Le Borgne, R., Faure, V., Raimbault, P., Rodier, M., 2004. Suivi de l'abondance de Trichodesmium spp. (cyanobactéries filamenteuses) et des paramètres du milieu lagonaire en Baie de SainteMarie (Nouméa, Nouvelle-Calédonie):7 octobre - 19 décembre 2003. Arch. Sc. Mer IRD/Nouméa 6, 1-50.

Le Borgne, R., Mazzeo, I., Raimbault, P., Rodier, M., Rouchon, C., 2006. Suivi de Trichodesmium spp. (cyanobactéries filamenteuses) et des paramètres du milieu lagonaire en baie de SainteMarie, Nouméa, Nouvelle-Calédonie. 3 novembre 2004 - 12 avril 2005. Arch. Sc. Mer IRD/Nouméa 8, 1-55.

Le Bouteiller, A., Blanchot, J., Rodier, M., 1992. Size distribution patterns of phytoplankton in the western Pacific: towards a generalization for the tropical ocean. Deep-Sea Res 39, 803-823.

Lenes, J.M., Walsh, J.J., Otis, D.B., Carder, K.L., 2005. Iron fertilization of Trichodesmium off the west coast of Barbados: A one-dimensional numerical model. Deep-Sea Res. I 52, 1021-1041. Letelier, R. M., Karl, D. M., 1996. Role of Trichodesmium spp. in the productivity of the subtropical North Pacific Ocean. Mar. Ecol. Prog. Ser. 133, 263-273. 
Lugomela, C., Lyimo, T. J., Bryceson, I., Semesi, A. K., Bergman, B., 2002. Trichodesmium in coastal waters of Tanzania: diversity, seasonality, nitrogen and carbon fixation. Hydrobiologia 477, 1-13.

Mills, M. M., Ridame, C., Davey, M., La Roche, J., Geider, R. J., 2004. Iron and phosphorus colimit nitrogen in the tropical North Atlantic. Nature 429, 292-294.

Moutin, T., Van Den Broeck, N., Beker, B., Dupouy, C., Rimmelin, P., Le Bouteiller, A., 2005. Phosphate availability controls Trichodesmium spp. biomass in the SW Pacific Ocean. Mar. Ecol. Prog. Ser. 297, 15-21.

Mulholland, M. R., Capone D. G., 2000. The nitrogen physiology of the marine $\mathrm{N}_{2}$-fixing cyanobacterium Trichodesmium spp.. Trends Plant Sci. 5, 148-153.

Mulholland, M. R., Bernhardt, P. W., 2005. The effect of growth rate, phosphorus concentration, and temperature on $\mathrm{N}_{2}$ fixation, carbon fixation, and nitrogen release in continuous cultures of Trichodesmium IMS 101. Limnol. Oceanogr. 50, 839-849.

Murphy, J., Riley, J.P., 1962. A modified single solution method for the determination of phosphate in natural waters. Anal. Chim. Acta 26, 31-36.

Muslim, I., Jones, G.B., 2003. The seasonal variation of dissolved nutrients, chlorophyll $a$ and suspended sediments at Nelly Bay, Magnetic Island. Estuar. Coastal Shelf Sci. 57, 445-455.

Negri, A.P., Bunter, O., Brian, J., Llewellyn, L., 2004. Effects of the bloom-forming alga Trichodesmium erythraeum on the pearl oyster Pinctada maxima. Aquaculture 232, 91-102.

Ohki, K., 1999. A possible role of temperate phage in the regulation of Trichodesmium biomass. Bull. Inst. Océanogr. Monaco 19, 287-291.

O’Neil, J. M., Roman M. R., 1994. Ingestion of the cyanobacterium Trichodesmium spp. by pelagic harpacticoid copepods Macrosetella, Miracia and Oculosetella. Hydrobiologia 292/293, 235240. 
O'Neil, J.M., Metzler, P.M., Glibert, P.M., 1996. Ingestion of ${ }^{15} \mathrm{~N}_{2}$-labeled Trichodesmium spp. and ammonium regeneration by the harpacticoid copepod Macrosetella gracilis. Mar. Biol. 125, 89-96.

Orcutt, K. M., Lipschultz, F., Gundersen, K., Arimoto, R., Michaels, A. F., Knap, A. H., Gallon, J. R., 2001. A seasonal study of the significance of $\mathrm{N}_{2}$ fixation by Trichodesmium spp. at Bermuda Atlantic Time-series Study (BATS) site. Deep-Sea Res. II 48, 1583-1608.

Post, A. F., Dedej, Z., Gottlieb, R., Li, H., Thomas, D. N., El-Absawi, M., El-Naggar, A., ElGharabawi, M., Sommer, U., 2002. Spatial and temporal distribution of Trichodesmium spp. in the stratified Gulf of Aqaba, Red Sea., Mar. Ecol. Prog. Ser. 239, 241-250.

Prufert-Bebout, L., Paerl, H.W., Lassen, C., 1993. Growth, nitrogen fixation and spectral attenuation in cultivated Trichodesmium species. Appl. Environ. Microbiol. 59, 1367-1375.

Raimbault, P., Slawyk, G., Coste, B., Fry, J., 1990. Feasibility of using an automated colorimetric procedure for the determination of seawater nitrate in the 0 to $100 \mathrm{nM}$ range: examples from field and culture, Mar. Biol. 104, 375-351.

Revelante, N., Gilmartin, M., 1982. Dynamics of phytoplankton in the Great Barrier Reef Lagoon. J. Plankton Res. 4, 47-76.

Riedel, G.F., J. G. Sanders, Breitburg, D. L., 2003. Seasonal Variability in Response of Estuarine Phytoplankton Communities to Stress: Linkages between Toxic Trace Elements and Nutrient Enrichment. Estuaries 26, 323-338.

Roman, M.R., 1978. Ingestion of the blue-green algae Trichodesmium by the harpacticoid copepod, Macrosetella gracilis. Limnol. Oceanogr. 23, 1245-1255.

Saino, T., Hattori, A., 1980. Nitrogen fixation by Trichodesmium and its significance in nitrogen cycling in the Kuroshio area and adjacent waters. In: Takenouti, A.Y. (Ed), The Kuroshio. Saikon Publishing, Tokyo, pp. 697-709. 
Sanudo-Wilhelmy, S. A., Kustka, A. B., Gobler, C. J., Hutchins, D. A., Yang, M., Lwiza, K., Burns, J., Capone, D. G., Raven, J. A., Carpenter, E. J., 2001. Phosphorus limitation of nitrogen fixation by Trichodesmium in the central Atlantic Ocean. Nature 411, 66-69.

Sarthou, G., Timmermans, K. R., Blain, S., Tréguer, P., 2005. Growth physiology and fate of diatoms in the ocean: a review. Journal of Sea Research 53, 25-42.

Satô, S., Paranagua, M.N., Eskinazi, E., 1963. On the mechanism of red tide of Trichodesmium in Recife, northeastern Brazil, with some considerations of the relation to the human disease “Tamandare fever". Trab. Inst. Oceanogr. Univ. Recife 6/7, 7-49.

Sellner, K.G., 1997. Physiology, ecology and toxic properties of marinecyanobacteria blooms. Limnol. Oceanogr 42, 1089-1104.

Snedecor, G.W., Cochran, W.G., 1967. Statistical methods, 6th ed.. Iowa State Univ. Press.

Strickland, J., Parsons, T., 1972. A practical handbook of seawater analysis, Fish Res. Bd Can. Bul. 167.

Tenório, M. M. B., Le Borgne, R., Rodier, M., Neveux, J., 2005. The impact of terrigeneous inputs on the Bay of Ouinné (New Caledonia) phytoplankton communities : a spectrofuorometric and microscopic approach. Estuar. Coastal Shelf Sci. 64, 531-545.

Tenório, M. M. B., 2006. Les cyanobactéries pélagiques en milieu tropical oligotrophe: occurrence, distribution et dynamique. Univ. Paris VI Thesis, 1-359.

Trottet, A., 2003. Biodiversité des cyanobactéries filamenteuses du genre Trichodesmium dans l'océan Pacifique tropical sud-ouest. Mémoire DEA Univ. Paris VI, 1-26.

Tyrell, T., Maranon, E., Poulton, A. J., Bowie, A. R., Harbour, D. S., Woodward, E. M. S., 2003. Large-scale latitudinal distribution of Trichodesmium spp. in the Atlantic Ocean. J. Plankton Res., 25, 405-416.

Van Den Broeck, N., Moutin, T., Rodier, M., Le Bouteiller, A., 2004. Seasonal variations of phosphate availability in the SW Pacific Ocean near New Caledonia. Mar. Ecol. Prog. Ser. $268,1-12$. 
Villareal, T. A., Carpenter, E. J., 2003. Buoyancy regulation and potential for vertical migration in the oceanic cyanobacterium Trichodesmium. Microb. Ecol., 45, 1-10. 
Tables

Table 1

Main characteristics of the five Trichodesmium erythraeum blooms (* denotes presence of $T$. thiebautii).

\begin{tabular}{lccccc}
\hline Period & $\begin{array}{c}\text { Number of } \\
\text { peaks }\end{array}$ & $\begin{array}{c}\text { Difference } \\
\text { in time evolution } \\
\text { at } 6 \text { and } 0.5 \mathrm{~m}\end{array}$ & $\begin{array}{c}\text { Total } \\
\text { duration (d) }\end{array}$ & $\begin{array}{c}\text { Maximum } \\
\text { at } 0.5 \mathrm{~m} \\
\left(\text { trich. } \mathrm{L}^{-1}\right)\end{array}$ & $\begin{array}{c}\text { Maximum } \\
\text { at 6-7 m } \\
\left(\text { trich. } \mathrm{L}^{-1} \text { ) }\right.\end{array}$ \\
\hline 24 Nov - 14 Dec 2003 & 3 & No & 18 & 238.7 & 47.4 \\
13 - 20 Dec 2004* & 1 & at 6m, 2 d before & 7 & 244.6 & 20.7 \\
3 - 14 Jan 2005 & 1 & No & 11 & 81.5 & 14.8 \\
4 - 18 Feb 2005* & & No & 14 & 10.1 & 19.4 \\
29 Mar - 7 Apr 2005 & 1 & at 6m, 4 d before & 9 & 156.5 & 44.3 \\
\hline
\end{tabular}


Table 2

Exponential net increase rates ( $\mathrm{ki}$ in $\left.\mathrm{d}^{-1}\right)$ and corresponding doubling times $\left(\mathrm{d}_{\mathrm{A}, \mathrm{i}}\right.$ in $\left.\mathrm{d}\right)$ in parentheses, from changes in Trichodesmium population biovolume, at different depths (equations 1 and 2).

\begin{tabular}{|c|c|c|c|c|c|c|c|c|c|}
\hline \multirow{2}{*}{2003} & \multicolumn{4}{|c|}{ T. erythraeum } & \multirow{2}{*}{ 2004-2005 } & \multicolumn{2}{|c|}{ T. erythraeum } & \multicolumn{2}{|c|}{ T. thiebautii } \\
\hline & $10 \mathrm{~m}$ & $7 \mathrm{~m}$ & $4 \mathrm{~m}$ & $0.5 \mathrm{~m}$ & & $6 \mathrm{~m}$ & $0.5 \mathrm{~m}$ & $6 \mathrm{~m}$ & $0.5 \mathrm{~m}$ \\
\hline \multirow[t]{2}{*}{ 24-30 Nov } & & 0.36 & 0.43 & 0.36 & 13-12 Dec & 0.39 & 3.29 & 1.51 & 2.20 \\
\hline & & (1.9) & (1.6) & (1.9) & & (1.8) & $(0.2)$ & $(0.5)$ & $(0.3)$ \\
\hline \multirow[t]{2}{*}{ 3-9 Dec } & 0.24 & 0.68 & 0.61 & 0.72 & 3-14 Jan & 0.98 & 1.13 & & \\
\hline & (2.9) & $(1.0)$ & (1.1) & (1.0) & & $(0.7)$ & $(0.6)$ & & \\
\hline \multirow[t]{4}{*}{ 11-14 Dec } & & & 0.15 & 0.40 & 4-18 Feb & 0.19 & 0.52 & 0.23 & 0.94 \\
\hline & & & (4.6) & (1.7) & & $(3.7)$ & $(1.3)$ & (2.9) & $(0.7)$ \\
\hline & & & & & 29 Mar - 4 Apr & 0.67 & 0.59 & & \\
\hline & & & & & & (1.0) & $(1.2)$ & & \\
\hline
\end{tabular}


Table 3

Sizes of T. erythraeum and T. thiebautii during the 2003 and 2004-2005 surveys at Sta SM. Means \pm standard deviations, and range (in parenthesis) of size parameters for $n$ observations.

\begin{tabular}{|c|c|c|c|c|}
\hline & & $\begin{array}{l}\text { Width } \\
(\mu \mathrm{m})\end{array}$ & $\begin{array}{l}\text { Length } \\
(\mu \mathrm{m})\end{array}$ & $\begin{array}{l}\text { Volume } \\
\left(10^{3} \mu \mathrm{m}^{3}\right)\end{array}$ \\
\hline \multicolumn{5}{|c|}{ T. erythraeum } \\
\hline \multirow[t]{2}{*}{2003} & $0.5 m-10 m$ & $11.0 \pm 0.6$ & $477 \pm 190$ & $45.3 \pm 20.7$ \\
\hline & $n=2612$ & $(5.5-22.0)$ & $(56-1489)$ & $(5.3-426.1)$ \\
\hline \multirow[t]{2}{*}{ 2004-2005 } & $0.5 m-6 m$ & $10.5 \pm 1.4$ & $550 \pm 344$ & $48.4 \pm 34.8$ \\
\hline & $n=6362$ & $(5.5-22.0)$ & $(60-2675)$ & $(4.1-448.6)$ \\
\hline \multicolumn{5}{|l|}{ T. thiebautii } \\
\hline \multirow[t]{2}{*}{2003} & $0.5 m-10 m$ & $11.3 \pm 2.3$ & $822 \pm 499$ & $67.1 \pm 26.0$ \\
\hline & $n=8$ & $(8.2-16.5)$ & $(440-2031)$ & $(25.6$ - 96.9) \\
\hline \multirow[t]{2}{*}{ 2004-2005 } & $0.5 m-6 m$ & $5.7 \pm 1.0$ & $847 \pm 440$ & $22.0 \pm 16.4$ \\
\hline & $n=1618$ & $(5.5-11.0)$ & $(57-3386)$ & $(1.3-186.4)$ \\
\hline
\end{tabular}


Table 4

Trichodesmium carbon, nitrogen and chlorophyll $a$ content of the 2004-2005 survey: means, standard deviations (sd) and ranges.

\begin{tabular}{|c|c|c|c|c|c|c|c|c|}
\hline & \multicolumn{3}{|c|}{ Per colony } & \multicolumn{3}{|c|}{ Per trichome } & \multicolumn{2}{|c|}{ Ratio } \\
\hline & $\begin{array}{l}\text { Chl } a \\
\text { (ng) }\end{array}$ & $\begin{array}{c}\mathrm{C} \\
(\mu \mathrm{g})\end{array}$ & $\begin{array}{c}\mathrm{N} \\
(\mu \mathrm{g})\end{array}$ & $\begin{array}{l}\text { Chl } a \\
(\mathrm{ng})\end{array}$ & $\begin{array}{c}\mathrm{C} \\
(\mathrm{ng})\end{array}$ & $\begin{array}{c}\mathrm{N} \\
(\mathrm{ng})\end{array}$ & $\begin{array}{c}\mathrm{C} / \mathrm{N} \\
(\mathrm{mol} / \mathrm{mol})\end{array}$ & $\begin{array}{c}\mathrm{C} / \mathrm{Chl} a \\
\quad(\mathrm{~g} / \mathrm{g})\end{array}$ \\
\hline Mean \pm sd & $7.84 \pm 5.16$ & $1.25 \pm 0.29$ & $0.20 \pm 0.12$ & $0.44 \pm 0.26$ & $103.1 \pm 36.1$ & $16.8 \pm 5.7$ & $6.2 \pm 0.8$ & $265.1 \pm 161.5$ \\
\hline Range & $2.41-14.9$ & $0.79-1.57$ & $0.15-0.39$ & $0.17-0.92$ & $61.5-191.0$ & $10.7-28.0$ & $4.6-7.4$ & $87.0-486.5$ \\
\hline
\end{tabular}


Table 5

Trichodesmium spp. densities (as trich. $\mathrm{L}^{-1}$ ) literature review (Note: references considering colony abundance are not presented. Specific difference between T. erythraeum $\left({ }^{\S}\right)$ and T. thiebautii $(*)$ are reported when available. m: mean value; max: maximum value.

\begin{tabular}{|c|c|c|c|}
\hline Region & Depth & Density & Author(s) \\
\hline Sargasso and Caribbean & $0 \mathrm{~m}$ (range) & $0-49 *$ & Carpenter and Price (1977) \\
\hline seas & $15-200 \mathrm{~m}$ (range) & $0-294 *$ & \\
\hline Kuroshio (Japan) & $0-100 \mathrm{~m}(\max )$ & $40-50000$ & Saino and Hattori (1980) \\
\hline Great Barrier Reef lagoon & bloom (max) & 50,000 & Revelante and Gilmartin (1982) \\
\hline \multirow[t]{2}{*}{ Cleveland Bay (Australia) } & inshore "blooms" (m) & $8515^{\S}$ & Jones (1992) \\
\hline & offshore "blooms" (m) & $3300^{\S}$ & \\
\hline HOT Station (Hawaii) & $0-45 \mathrm{~m}$ (range) & $11-84$ & Letelier and Karl (1996) \\
\hline \multirow[t]{2}{*}{ Southwest tropical Pacific } & $0 \mathrm{~m}-\mathrm{Fiji}(\max )$ & 10,000 & Dupouy et al. (2000) \\
\hline & 0 m New Caledonia $(\max )$ & 1000 & \\
\hline \multirow[t]{2}{*}{ Tanzania coast } & $0 \mathrm{~m}$ "bloom" (range) & $38,000-120,000^{\S}$ & Lugomela et al. (2002) \\
\hline & $0-20 \mathrm{~m}$ (range) & $0-63,000^{\S}$ & \\
\hline Gulf of Aqaba & 0-90 m (range) & $0.05-2$ & Post et al. (2002) \\
\hline South China Sea & $0 \mathrm{~m}(\mathrm{~m}$, range $)$ & $77(0-962)$ & Chen et al. (2003) \\
\hline \multirow[t]{2}{*}{ Magnetic island (Australia) } & surface (range) & $9-102,000$ & Muslim and Jones (2003) \\
\hline & $15 \mathrm{~m}(\mathrm{~m})$ & 13,000 & \\
\hline \multirow[t]{2}{*}{ North and South Atlantic } & $7 \mathrm{~m}(\mathrm{~m})$ & 300 & Tyrell et al. 2003 \\
\hline & $(\max )$ & 2200 & \\
\hline $\begin{array}{l}\text { Dampier Archipelago } \\
\text { (Australia) }\end{array}$ & $0-20 \mathrm{~m}(\mathrm{~m})$ & $1800^{\S}$ & Negri et al. (2004) \\
\hline \multirow[t]{2}{*}{ North tropical Atlantic } & "surface" (m) & $222-292 *$ & Carpenter et al. (2004) \\
\hline & "surface", peak period (m) & 2250 (up to 10867$)^{*}$ & \\
\hline $\begin{array}{l}\text { Bay of Ouinné } \\
\text { (New Caledonia) }\end{array}$ & $0-45 \mathrm{~m}(\mathrm{~m})$ & $0.7-17^{\S} ; 0.6-29^{*}$ & Tenório et al. (2005) \\
\hline $\begin{array}{l}\text { Loyalty channel } \\
\text { (New Caledonia) }\end{array}$ & $0-60 \mathrm{~m}$ (range) & $0-1011^{\S} ; 4-2450^{*}$ & Tenorio (2006) \\
\hline Bay of Sainte Marie & $0.5 \mathrm{~m}$ (range) & $0-240^{\S} ; 0-34^{*}$ & Present study \\
\hline (New Caledonia) & $6 \mathrm{~m}$ (range) & $0-47^{\S} ; 0-18^{*}$ & \\
\hline
\end{tabular}


Table 6

Literature review of Trichodesmium carbon-specific doubling times (d).

Temperature Doubling time

Reference Conditions

$\left({ }^{\circ} \mathrm{C}\right) \quad$ (d)

Carpenter and Romans (1991)

natural populations, tropical -subtropical Atlantic

$26.5-28$

$1.8-18$

Carpenter and Capone (1992)

Review

$>27$

$3-6$

Carpenter et al. (1993)

natural populations

T. erythraeum

$26.5-28$

3.8

T. thiebautii

Prufert-Bebout et al. (1993)

Cultures

$3.0 *$

Mulholland and Capone (2000)

Cultures

natural populations

$3.8-198$

Orcutt et al. (2001)

natural populations, Bermuda

2

Bell et al. (2005)

Cultures

$25 \pm 3$

$2.3-3.5$

Mulholland and Bernhardt (2005)

continuous culture

28

$3-10$

Le Borgne et al. (2006)

natural populations, bloom, Bay of Ste Marie,

$27-29$

$4.1-5.8$

idem, non-bloom conditions

$27-29$

$13.9-40.8$ 
Table 7

Values of the trichome exponential net growth rate $\left(\mathrm{g}_{0.5}\right)$ and their corresponding doubling time $\left(\mathrm{d}_{\mathrm{A}, 0.5}\right)$ satisfying equation 4 , for $\mathrm{z}=0.5 \mathrm{~m}$. Percent contributions of net growth $\left(\mathrm{G}_{0.5} / \Delta \mathrm{V}_{0.5}\right)$ and ascent from deeper levels $\left(\mathrm{A}_{0.5} / \Delta \mathrm{V}_{0.5}\right)$ to observed biovolume increases at $0.5 \mathrm{~m}, \Delta \mathrm{V}_{0.5}$.

\begin{tabular}{ccccc}
\hline Period & $\mathrm{g}_{0.5}$ & $\mathrm{~d}_{\mathrm{A}, 0.5}$ & $\mathrm{~A}_{0.5} / \Delta \mathrm{V}_{0.5}$ & $\mathrm{G}_{0.5} / \Delta \mathrm{V}_{0.5}$ \\
& $\left(\mathrm{~d}^{-1}\right)$ & $(\mathrm{d})$ & $(\%)$ & $(\%)$ \\
\hline 24-28 Nov 2003 & 0.18 & 3.86 & 87.3 & 12.5 \\
3-5 Dec 2003 & 0.38 & 1.82 & 97.6 & 2.4 \\
10-12 Dec 2003 & 0.12 & 5.57 & 87.3 & 12.6 \\
13-15 Dec 2004 & 1.32 & 0.53 & 98.2 & 1.8 \\
3-5 Jan 2005 & 0.11 & 6.45 & 87.0 & 13.0 \\
25 Mar - 4 Apr 2005 & 0.17 & 4.14 & 98.9 & 1.1 \\
\hline
\end{tabular}




\section{Figure captions}

Fig. 1. Sampling station locations at the entrance (Sta. SM) and off (Sta. O) the Bay of Ste Marie.

Fig. 2. Trichodesmium abundance as trichome numbers versus biovolume during the 2003 and 20042005 surveys. Slopes (b) of the linear regressions are : $b=44240$ in 2003 and $b=45084$ in 20042005, respectively.

Fig. 3. Temporal variations in T. erythraeum biovolume at Sta. SM four sampled depths, during Survey I (2003). Note : T. thiebautii densities, contributing for $<1 \%$ of the total, have not been represented on the figure.

Fig. 4. Temporal variations in T. erythraeum and T. thiebautii biovolume at Sta SM two sampled depths, during Survey II (2004-2005). Less frequent observations were made at Sta. O, $0.5 \mathrm{~m}$ Fig. 5. Relationships between trichome in colony (y) and free trichome (x) densities during the 2003 and 2004-2005 surveys.

Fig. 6. Temporal variations of environmental variables and Trichodesmium spp. densities at Sta. SM during Survey I. Temperature and salinity refer to the $1 \mathrm{~m}$ depth. Nitrate $\left(\mathrm{NO}_{3}\right)$, Soluble Reactive Phosphorus (SRP) and chlorophyll $a(\mathrm{Chl} a)$ concentrations are averaged through the $0-12 \mathrm{~m}$ water column, wind velocities, on $24 \mathrm{~h}$. Significant rainfall $\left(>10 \mathrm{~mm} \mathrm{~d}^{-1}\right)$ are indicated by vertical arrows. Trichodesmium spp. abundances are integrated over $10 \mathrm{~m}$.

Fig.7. Same as Fig. 3, but for Survey II.

Fig. 8. Trichodesmium peak amplitude versus nitrate concentration at the beginning of the five blooms. 


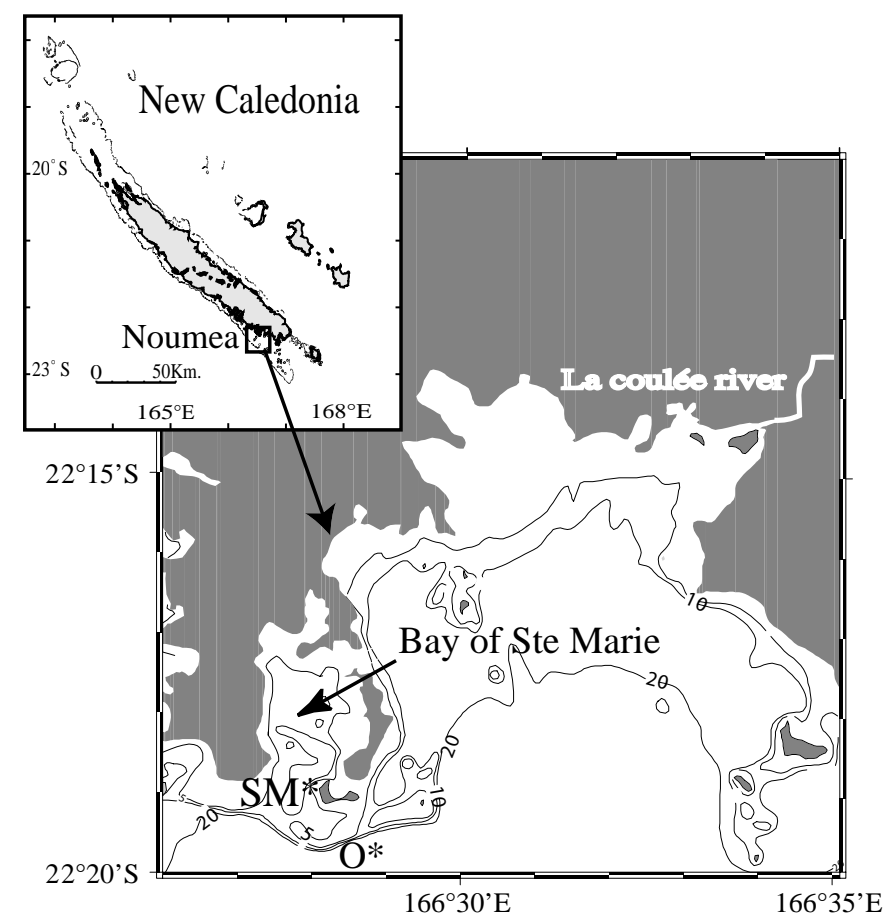

Fig. 1 


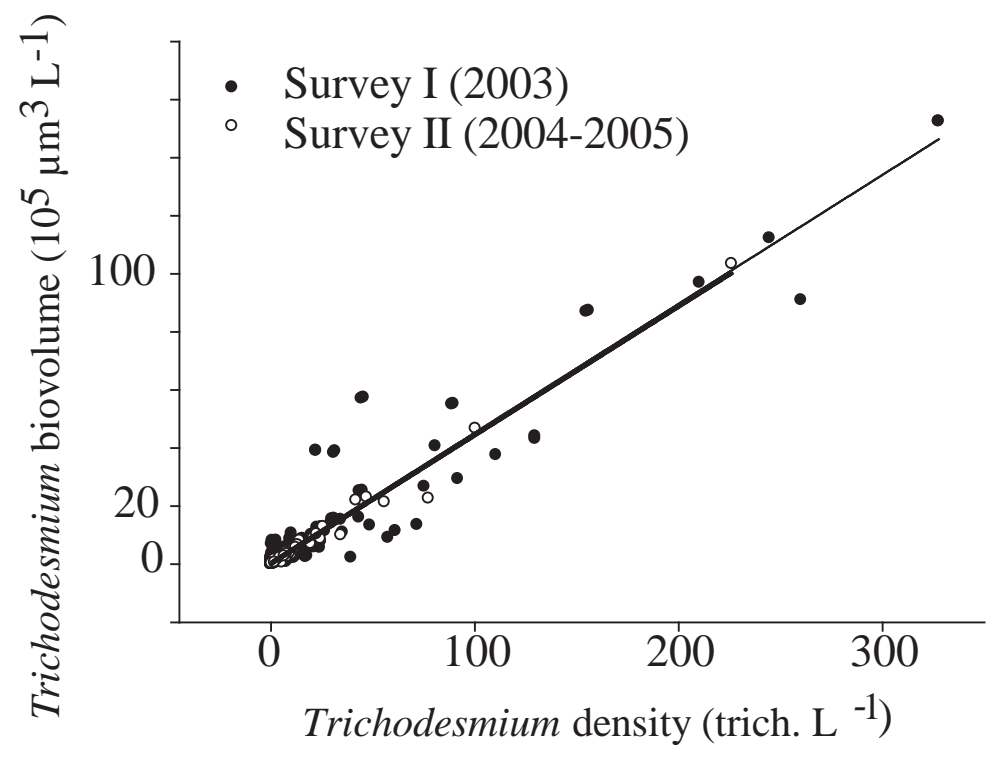

Fig. 2 


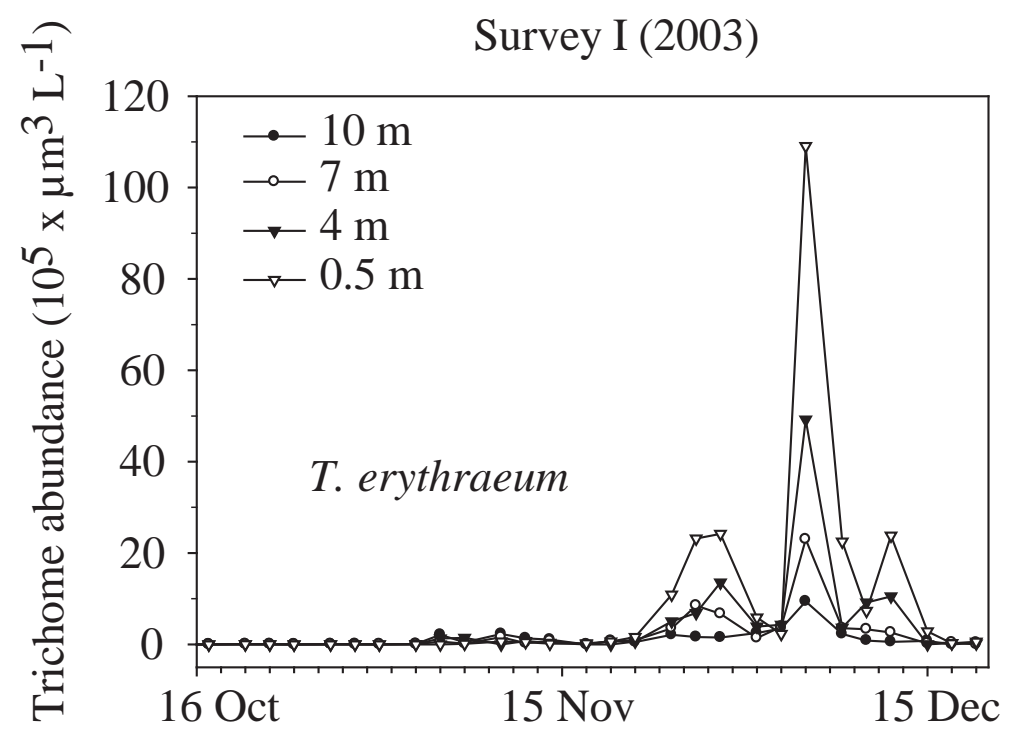

Fig. 3 
Survey II (2004-2005)

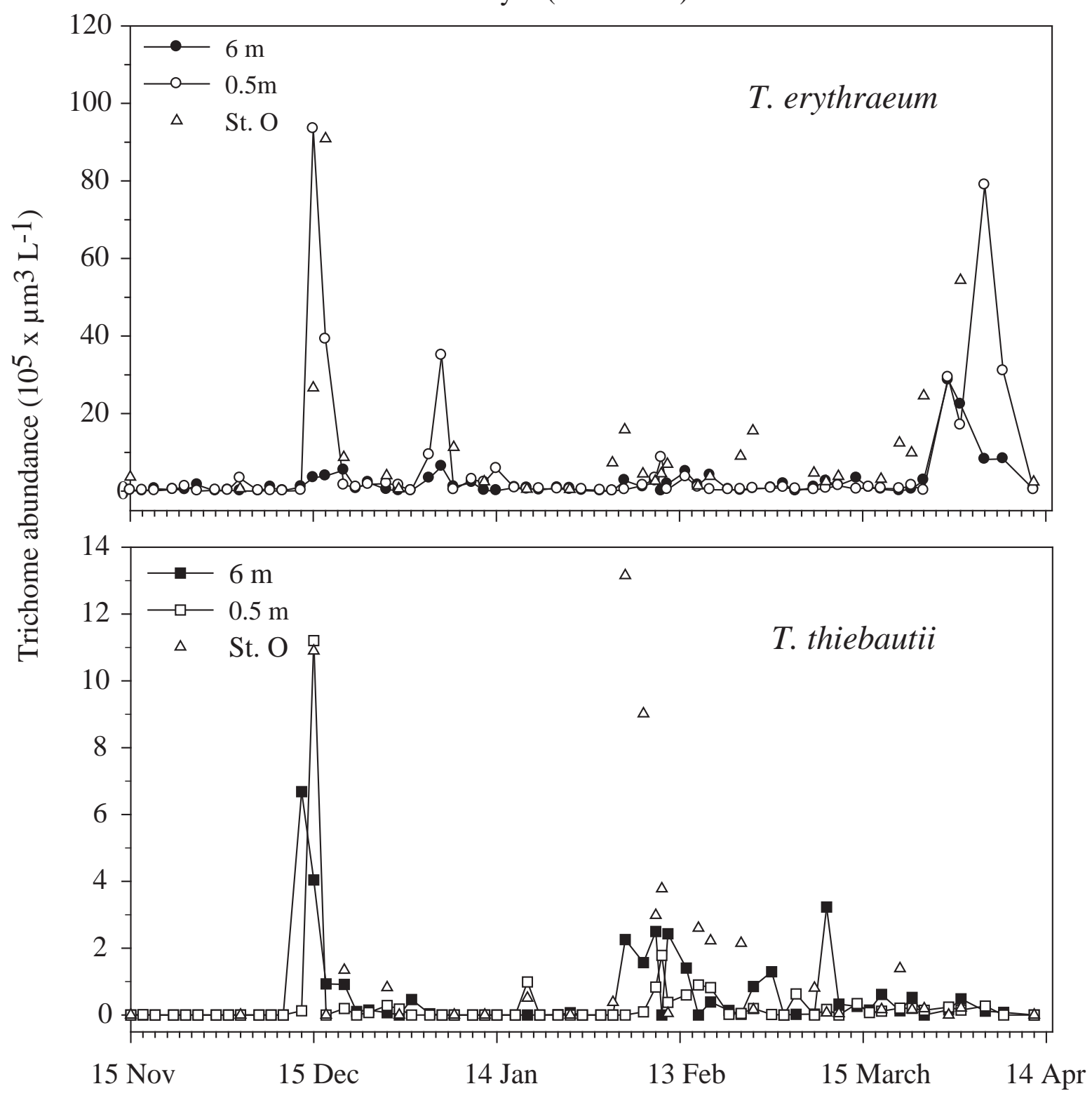

Fig. 4 


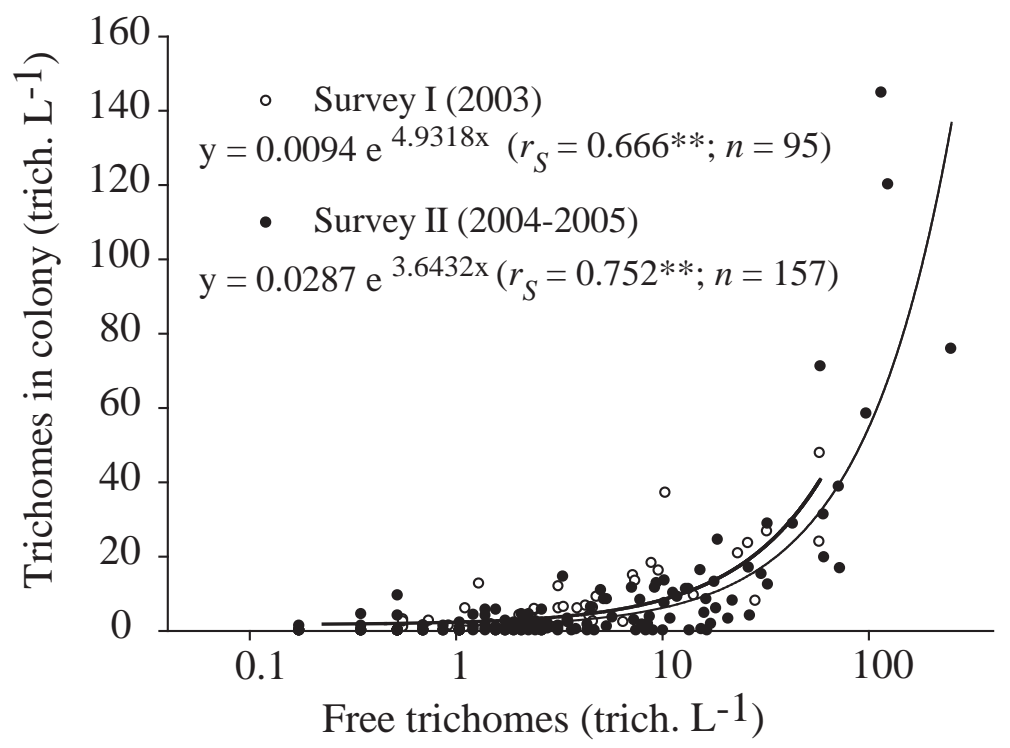

Fig. 5 
Survey I (2003)
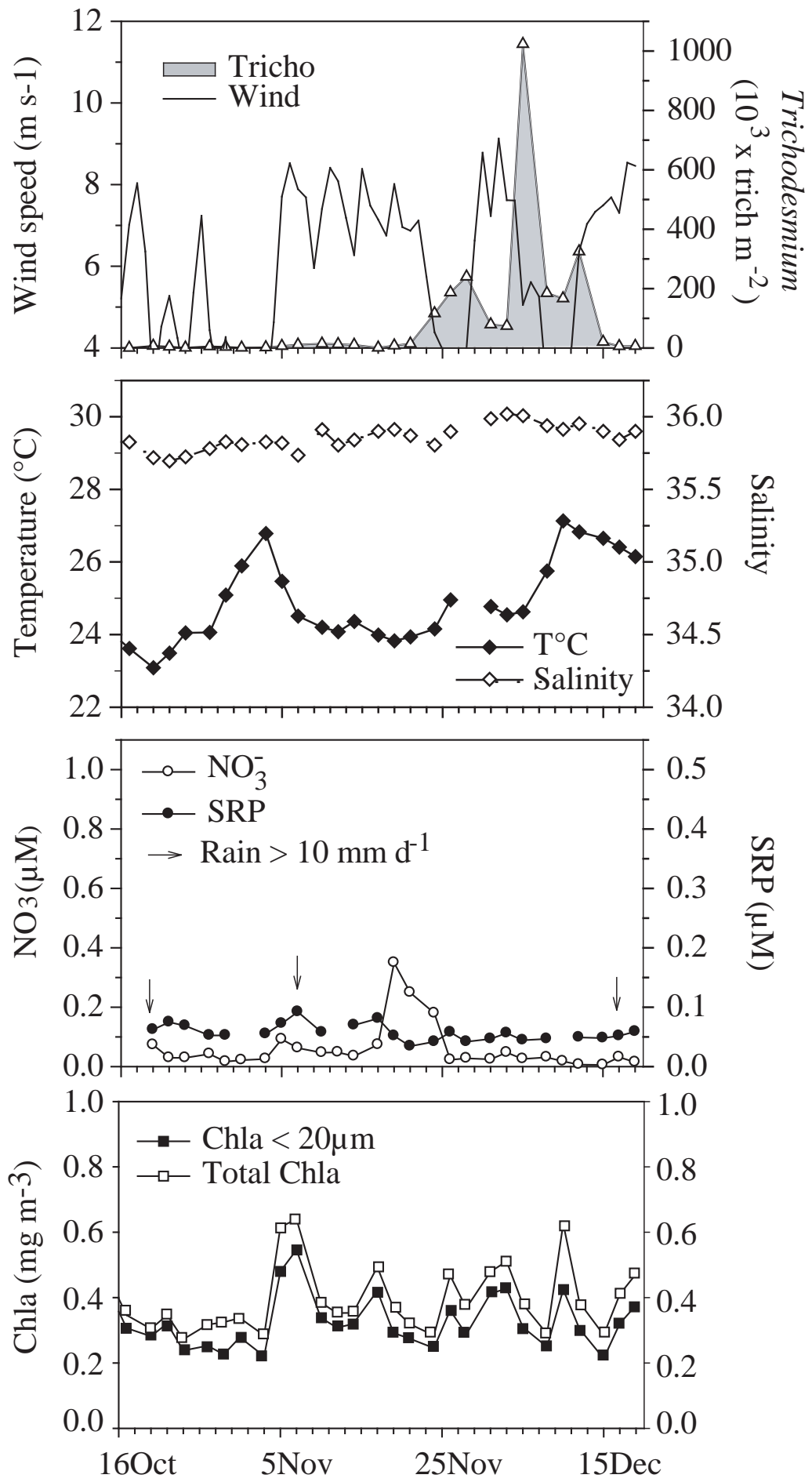

Fig.6 
Survey II (2004-2005)
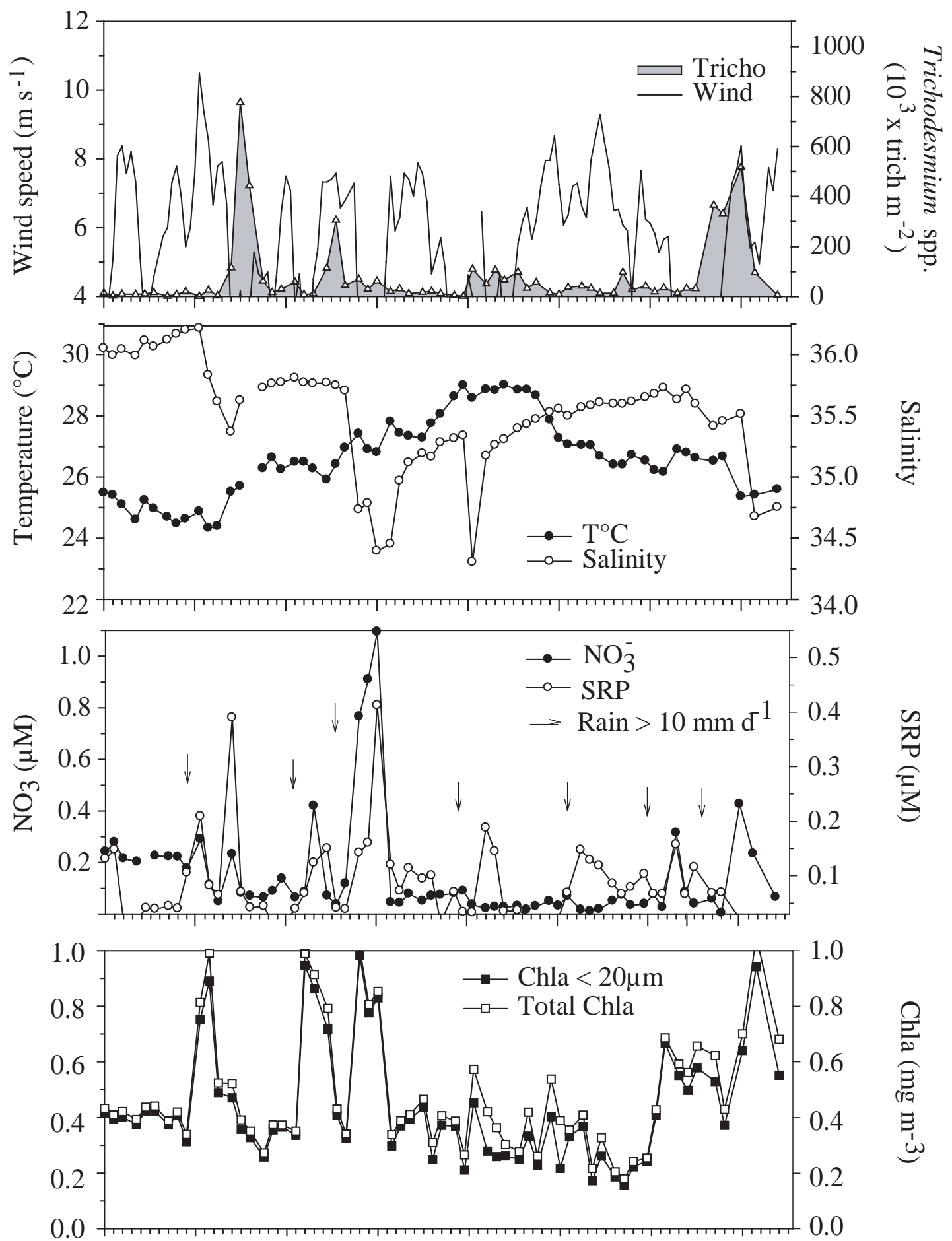

15 Nov 5 Dec 25 Dec 14 Jan 3 Feb 23 Feb 15 March 4 Apr

Fig. 7 


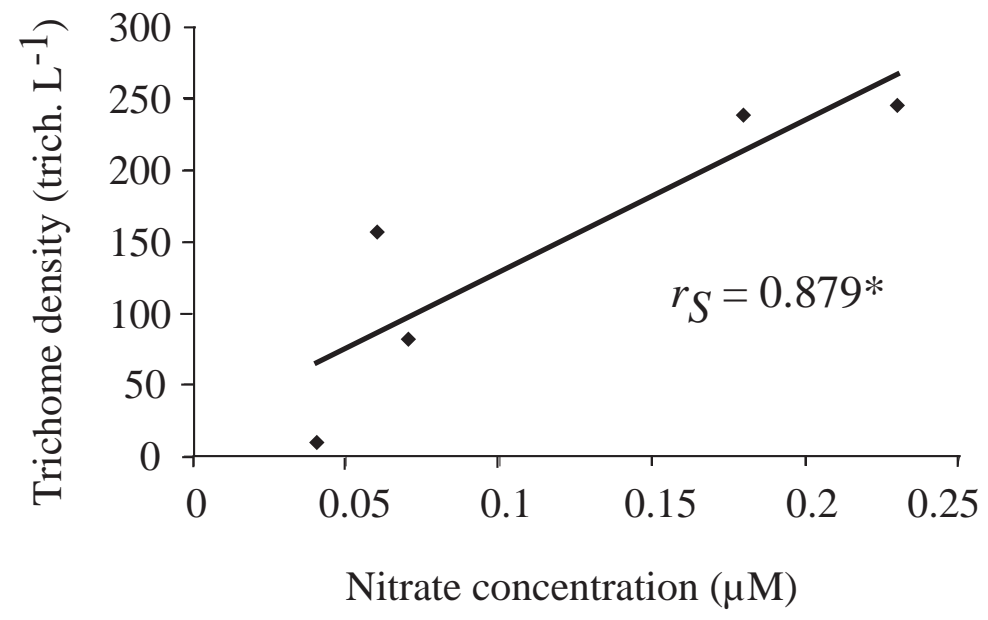

Fig. 8 